\title{
Henry Bate's Tabule Machlinenses: The earliest astronomical tables by a Latin author
}

\author{
C. Philipp E. Nothaft \\ All Souls College, Oxford
}

\section{Summary}

The known works of the medieval astronomer/astrologer Henry Bate (1246-after 1310) include a set of planetary mean motion tables for the meridian of his Flemish hometown Mechelen. These tables survive in three manuscripts representing two significantly different recensions, but have never been examined for their principles of construction or underlying parameters. Such analysis reveals that Bate employed an unusual value for the length of the tropical year (c.365 1/4 - 1/112 days), which was probably derived by comparing ancient and contemporary observations of the vernal equinox. In addition, there are clear signs that Bate kept revising his parameters for the mean motions of Venus and the three superior planets, none of which can be traced back to earlier sources. Together with some of Bate's preserved statements, these findings support the conclusion that the Tabule Machlinenses were unique among the astronomical tables produced in medieval Latin Christendom for using independently derived parameters that were the result of new observations. Bate's achievement connects him to a wider milieu of astronomers operating in late-thirteenthcentury Paris, who put an increased emphasis on observation and the critical examination of received data.

\section{Keywords}

Henry Bate; Abraham Ibn Ezra; William of Saint-Cloud; Ptolemy; Paris; medieval astronomy; astronomical tables; astronomical observations 


\section{Contents}

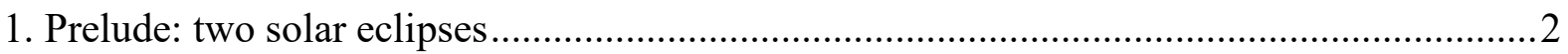

2. Background: astronomical tables in High Medieval Europe ............................................ 7

3. The two extant versions of the Tabule Machlinenses .......................................................... 14

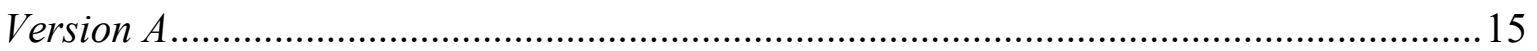

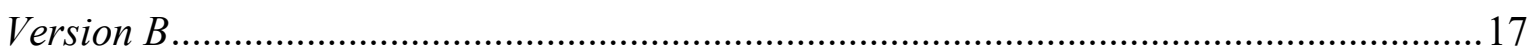

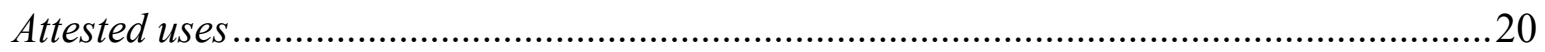

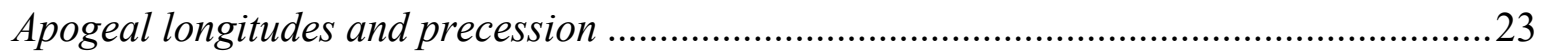

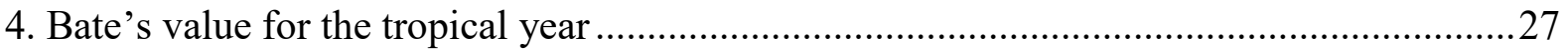

5. Mean motion parameters in the Tabule Machlinenses ....................................................39

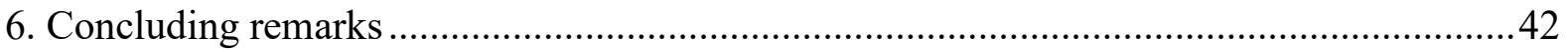

\section{Prelude: two solar eclipses}

The latest securely attested date in the life of Henry Bate of Mechelen, the noted Flemish philosopher and translator of Hebrew astrological texts, ${ }^{1}$ belongs to an annular solar eclipse he observed on 31 January AD 1310. At its mid-point, which was reached early in the afternoon, 'the radiance of the Sun, which was like a circle that protruded from the Moon

\footnotetext{
${ }^{1}$ On Bate's life and work, see the introductory chapters in Carlos Steel, Steven Vanden Broecke, David Juste, and Shlomo Sela, eds., The Astrological Biography of a Medieval Philosopher: Henry Bate's Nativitas (128081) (Leuven: Leuven University Press, 2018). Further literature is cited in Olga Weijers, Le travail intellectuel à la Faculté des arts de Paris: textes et maîtres (ca. 1200-1500), 9 vols. (Turnhout: Brepols, 1994-2012), IV, pp. $45-48$.
} 
equally on all sides, appeared through the medium of some fairly transparent clouds'. ${ }^{2}$ Bate offers this description in an addendum to Part XXII of his Speculum divinorum et quorundam naturalium, a voluminous philosophical encyclopaedia he composed between 1301 and 1305 . The chapters preceding this postscript are mostly an attack on Simplicius of Cilicia, the sixthcentury Neoplatonist, who tried to reconcile the apparent espousal of a concentric model of the heavens in Aristotle's De caelo with the reality of epicycles and eccentric deferents, as described in Ptolemy's Almagest and Planetary Hypotheses. ${ }^{3}$ Bate resolutely rejected Ptolemy's planetary models as running contrary to the principles of nature, which committed him to arguing that the observational evidence Simplicius and others had cited in their favour was due to optical illusions or instrumental error. An important test case for his ability to explain away such evidence were annular solar eclipses, which created a problem both for Ptolemy, whose parameters did not allow the Sun to appear larger than the Moon, and for the adherents to a homocentric universe, who treated as invariant the distances between the Earth and the celestial luminaries. ${ }^{4}$ That the bright ring of sunlight that encircled the Moon during

\footnotetext{
${ }^{2}$ See n. 12 below for the relevant quotation.

${ }^{3}$ Henry Bate, Speculum divinorum et quorundam naturalium XX.14-18, ed. Carlos Steel and Guy Guldentops (Leuven: Leuven University Press, 1996), pp. 322-346. On Simplicius's defence of Ptolemy, see Alan C. Bowen, Simplicius on the Planets and Their Motions: In Defense of a Heresy (Leiden: Brill, 2013). On Bate's use and criticism of Simplicius, see Fernand Bossier, 'Traductions latines et influences du commentaire In De caelo en occident (XIIIe-XIVe s.)', in Simplicius: sa vie, son oeuvre, sa survie, ed. Ilsetraut Hadot (Berlin: de
} Gruyter, 1987), pp. 289-325 (311-320).

${ }^{4}$ See on this point S. Mohammad Mozaffari, 'Annular Eclipses and Considerations about Solar and Lunar Angular Diameters in Medieval Astronomy', in New Insights from Recent Studies in Historical Astronomy: Following in the Footsteps of F. Richard Stephenson, ed. Wayne Orchiston, David A. Green, and Richard Strom (Cham, Switzerland: Springer, 2015), pp. 119-142. 
certain eclipses created a big stumbling block for the latter sort of theory was recognized by one of Bate's contemporaries, the Franciscan astronomer Guido de Marchia, who cited the aforementioned eclipse of $\mathrm{AD} 1310$ as one of the reasons why a homocentric system like that proposed by al-Bițūjī deserved no credence. ${ }^{5}$

Bate remained unperturbed by such objections, claiming that the phenomenon could just as well be the result of refraction, caused by a diaphanous medium such as clouds, which was known to distort the size of illuminated (or luminescent) celestial objects, while leaving dark ones unaffected. Did not the same sort of illusion occur at the start and end of each lunar month, when the illuminated crescent of the Moon gave the sensible impression of being part of a larger object than the unilluminated part, to the extent that the extremities of the horned crescent sometimes appeared to overhang the circumference of its total disk? ${ }^{6}$ Far from being worried about the threat annular eclipses might pose to his philosophy, Bate supplemented the relevant chapter of his Speculum by mentioning not just one, but two recent cases. The earlier of these had supposedly been witnessed over Paris on the afternoon of 12 April AD 1298, when the low altitude of the luminaries and the thickness of the air caused by a prior rainfall conspired to make the Sun cast its illusory ring of light around the Moon's edges. ${ }^{7}$ If the second-hand report Bate had received about this eclipse was correct, it could also be used to undermine one of his philosophical opponents, the ninth-century astronomer al-Battānī, whose modified Ptolemaic theory allowed the Sun's apparent diameter to vary between $0 ; 31,20^{\circ}$ and $0 ; 33,40^{\circ}$. Since the lunar diameter could, on his account, appear as small as

\footnotetext{
${ }^{5}$ Michael H. Shank, 'Rings in a Fluid Heaven: The Equatorium-Driven Physical Astronomy of Guido de Marchia (fl. 1292-1310)', Centaurus, 45 (2003), 175-203 (187-188).

${ }^{6}$ Bate, Speculum XX.18, ed. Steel and Guldentops (n. 3), p. 344.

${ }^{7}$ Bate, Speculum XX.18 (additio), ed. Steel and Guldentops (n. 3), p. 346.
} 
$0 ; 29,30^{\circ}$, annular eclipses were well within the range of phenomena predicted by the theory. ${ }^{8}$ Yet in the case of 12 April AD 1298, al-Battānī's own tables indicated that the true lunar anomaly at the time of mid-eclipse was close to $235^{\circ}$, which, on Bate's calculation, would have gone hand in hand with an apparent diameter of approximately $0 ; 34,5^{\circ}$. The eclipse should therefore have been total rather than annular, which in Bate's mind raised serious doubts about the capabilities of Ptolemy's followers to obtain from observation reliable parameters for the prediction of angular diameters. ${ }^{9}$

As neat and attractive as this argument may have appeared to him, Henry Bate knew perfectly well that there were reasons to recoil from it. Indeed, the available astronomical tables, his own included, all indicated that the Moon on 12 April AD 1298 had been more than $12^{\circ}$ removed from its nearest point of intersection with the ecliptic, under which circumstances no eclipse should have been visible on that date. ${ }^{10}$ Bate was not the kind of thinker who put blind trust in the principles and assumptions that underpinned contemporary astronomy. And yet, the predictive success of his own computational tables, which he had cast for the meridian of Mechelen, seemed too solid and consistent to make the testimony of his informant easily acceptable.

According to all astronomical tables that have reached us to date, and this includes our [Tables of] Mechelen, which have now already undergone their third and greatest correction $[. .$.$] one finds that at the aforementioned eclipse the Moon's distance from$ the node of the Dragon was greater than 12 degrees around the mid-point of the time of its visibility. I would therefore be in awe at an eclipse of this type or would be loath

\footnotetext{
${ }^{8}$ al-Battān̄i, De motu stellarum, c. 30, trans. Plato of Tivoli (Nuremberg: Petreius, 1537), fols. 37v-39r.

${ }^{9}$ Bate, Speculum XX.18 (additio), ed. Steel and Guldentops (n. 3), pp. 346-347.

${ }^{10}$ The tables were correct, at least in so far as the eclipse of 12 April AD 1298 was partial and barely visible from Paris. See https://eclipse.gsfc.nasa.gov/SEcat5/SE1201-1300.html [accessed 26 October 2018].
} 
to put my faith in the informant, unless there is a defect and error in the principles and assumptions of the astronomers and the models of [celestial] motion and, as a consequence, in the tables that are founded on [these principles]. Yet our [own tables], which were corrected by seizing upon ancient and modern observations [...] are certainly found to agree with the appearances more so than the others, as also became manifest and conspicuous to the eyes in the Year of our Lord $1309,{ }^{11}$ on the final day of January [...]. In the end, one should not completely spurn the aforementioned tables. For through them, which were adjusted to observations made by Ptolemy in the past and by us later on, and which agree with truth-conveying experience, it is possible to find the positions of the planets and their conjunctions, and also the revolutions of the years and their quarters. ${ }^{12}$

\footnotetext{
${ }^{11}$ It was an established Parisian practice to begin the year on Easter Sunday, explaining why Bate assigned the solar eclipse of 31 January 1310 to the year 1309 . He comments on this dating style in his astrological autobiography (1280-81), calling it the consuetudo patrie nostre. See Henry Bate, Nativitas, 11. 40-43, ed. Steel et al. (n. 1).

${ }^{12}$ Bate, Speculum XX.18 (additio), ed. Steel and Guldentops (n. 3), pp. 347-348: 'Sane secundum omnes tabulas astrologicas quae ad nos hucusque pervenerunt, ac etiam nostras Machlinenses tertio iam et ultimo correctas, eas inquam quae super astrologicas radices et principia fundatae sunt, in eclipsi memorata circa medium tempus ipsius visibilis repertum est lunae distantiam a nodo Draconis maiorem fore 12 gradus.
} Quapropter de possibilitate quidem eclipsis talis admirarer aut relatori fidem non adhiberem nisi quia defectus et error est in principiis et positionibus astrologicis ac imaginationibus motuum et per consequens in tabulis etiam super huiusmodi radicatis. Nostrae tamen quae per antiquarum quidem et modernarum observationum deprehensionem correctae sunt, prout suppositis principiis astrologicis nobis possibile fuit, prae ceteris utique magis inveniuntur apparentibus concordare, quemadmodum et anno domini nostri Iesu Christi $1309^{\circ}$ postrema die ianuarii manifeste compertum est ac sensibili aspectu visum in quadam solis eclipsi, in cuius medio tempore veluti circa lunam aequaliter eminens undique circulus quidam solaris iubaris per intermediam satis perviae 


\section{Background: astronomical tables in High Medieval Europe}

What makes the just-cited statement particularly striking is Bate's unambiguous insistence on the idea that his own tables, the Tabule Machlinenses, were the result of careful empirical labour, which involved the performance of fresh astronomical observations as well as the comparison of these observations with earlier ones, in particular those recorded in Ptolemy's Almagest. During the twelfth and thirteenth centuries, the mainstream of computational astronomy in Latin Europe was under the sway of the so-called Toledan Tables, whose origins are found in the vibrant Andalusian astronomical scene of the second half of the eleventh century. ${ }^{13}$ In addition to the over 160 extant Latin manuscripts that attest to the use of these tables in their unadulterated form, as characterized by the Islamic calendar and the reference meridian of Toledo, ${ }^{14}$ there are numerous examples where Latin Christian

nubis transparentiam apparebat. Demum neque spernendae sunt omnino nostrae praefatae tabulae; per ipsas enim concordatas utique considerationibus a Ptolemaeo prius observatis et a nobis posterius experientiaeque veraci convenientes inveniri possunt loca planetarum et eorum coniunctiones, anni quoque simul et quartarum eius revolutiones'.

${ }^{13}$ Fritz S. Pedersen, The Toledan Tables: A Review of the Manuscripts and the Textual Versions with an Edition, 4 vols. (Copenhagen: Reitzel, 2002). For the wider background, see Raymond Mercier, 'Astronomical Tables in the Twelfth Century', in Adelard of Bath: An English Scientist and Arabist of the Early Twelfth Century, ed. Charles Burnett (London: Warburg Institute, 1987), pp. 87-118, repr. in idem, Studies on the Transmission of Medieval Mathematical Astronomy (Aldershot: Variorum, 2004), art. VII; David A. King and Julio Samsó, ‘Astronomical Handbooks and Tables from the Islamic World (750-1900): An Interim Report', Suhayl, 2 (2001), 9-105; José Chabás and Bernard R. Goldstein, A Survey of European Astronomical Tables in the Late Middle Ages (Leiden: Brill, 2012); José Chabás, ‘Aspects of Arabic Influence on Astronomical Tables in Medieval Europe', Suhayl, 13 (2014), 23-40.

${ }^{14}$ See the rough count provided by Pedersen, The Toledan Tables (n. 13), I, p. 13. 
astronomers made the computational effort to adapt the Toledan mean-motion tables to their own calendars and meridians, thereby rendering their use more convenient and their results more adequate to local conditions. Surviving examples from the twelfth century are the tables for the meridian of Marseilles by Raymond of Marseilles (1141) and the tables for Hereford by Roger of Hereford (1178). ${ }^{15}$ This activity picked up pace in the thirteenth century, as seen, for instance, from another set of tables for Marseilles by William the Englishman (fl. 12191231), ${ }^{16}$ from the Tables of Ferrara by a certain Iohannes, ${ }^{17}$ from the Tables of Novara by Campanus of Novara, ${ }^{18}$ from a widespread anonymous set of tables for the meridian of Toulouse, ${ }^{19}$ and from tables in the French vernacular cast for the meridian of Paris $(c .1271) .{ }^{20}$

\footnotetext{
15 The tables by Raymond of Marseilles were part of his Liber cursuum planetarum, ed. Marie-Thérèse d'Alverny, Charles Burnett, and Emmanuel Poulle, eds., Raymond de Marseille: Opera omnia, vol. 1, Traité de l'astrolabe, Liber cursuum planetarum (Paris: CNRS éditions, 2009), pp. 126-341. For the tables of Roger of
} Hereford, see MSS Madrid, Biblioteca nacional de España, 10016, fols. 73r-83v, 85r; London, British Library, Arundel 377, fols. $86 \mathrm{v}-87 \mathrm{r}$.

${ }^{16}$ MS Edinburgh, Royal Observatory, Crawford 2.5, fols. 92r-96v. The collected-year entries here generally range from 1160 to 1260 (occasionally to 1280 or 1300), although the table for Jupiter begins with 1140 .

${ }^{17}$ MS Paris, Bibliothèque de l'Arsenal, 1128, fols. 1r-28v. The epoch date here is 1 March 1204.

${ }^{18}$ Pedersen, The Toledan Tables (n. 13), III, pp. 1205-1207.

${ }^{19}$ Emmanuel Poulle, 'Un témoin de l'astronomie latine du XIII' siècle: les tables de Toulouse', in Comprendre et maîtriser la nature au Moyen-Âge: mélanges d'histoire des sciences offerts à Guy Beaujouan (Geneva: Droz, 1994), 55-81, repr. as ch. 1 in Astronomie planétaire au Moyen Âge latin (Aldershot: Variorum, 1996); Fritz S. Pedersen, 'The Toulouse Tables: A List of Manuscripts', Cahiers de l'Institut du Moyen-Âge Grec et Latin 68 (1998): 3-12; Pedersen, The Toledan Tables (n. 13), III, pp. 1197-1205.

${ }^{20}$ Jean-Patrice Boudet and Matthieu Husson, 'The Earliest Astronomical Tables in French (c. 1271)', Journal for the History of Astronomy, 43 (2012), 287-298; Boudet and Husson, 'Le vocabulaire de l'astronomie en ancien français: le cas des tables et canons de ca. 1271', Neologica, 7 (2013), 57-86. 
Significantly, none of these examples involved any alterations to the fundamental mean motion parameters, the equation tables, or the planetary models at the heart of the Toledan Tables, which hence came close to providing a common standard for computational astronomy in Latin Europe prior to the dissemination of the Alfonsine Tables in the fourteenth century. ${ }^{21}$ Leaving aside the tables of al-Khwārizmī, which were first rendered into Latin $c .1116$, but quickly cast aside in favour of the Toledan Tables, ${ }^{22}$ the main alternative available to Christian astronomers during this pre-Alfonsine period were the tables compiled by Abraham Ibn Ezra (c. 1089-c.1161) on the basis of the lost tenth-century $z \bar{j} j$ of al-Ṣufî. ${ }^{23}$ These tables differed from the Toledan ones in a number of important respects, for instance by assuming a tropical rather than a sidereal reference frame for the computation of planetary longitudes and a steady rate of precession for the corresponding apogees. ${ }^{24}$ In this

\footnotetext{
${ }^{21}$ The Alfonsine Tables were the work of Jewish astronomers at the court of King Alfonso X of Castile and León (1252-1284). They seem to date from 1263/72, but only began to be used in Paris c.1320. See José Chabás and Bernard R. Goldstein, The Alfonsine Tables of Toledo (Dordrecht: Kluwer, 2003); Noel Swerdlow,
} 'Alfonsine Tables of Toledo and Later Alfonsine Tables', Journal for the History of Astronomy, 35 (2004), 479484.

${ }^{22}$ Mercier, ‘Astronomical Tables’ (n. 13), pp. 88-102.

${ }^{23}$ Raymond Mercier, 'The Lost Zīj of al-Ṣūfì in the Twelfth-Century Tables for London and Pisa', in idem, Studies on the Transmission of Medieval Mathematical Astronomy (Aldershot: Variorum, 2004), art. VIII; Charles Burnett, 'The Transmission of Arabic Astronomy via Antioch and Pisa in the Second Quarter of the Twelfth Century', in The Enterprise of Science in Islam: New Perspectives, ed. Jan P. Hogendijk and Abdelhamid I. Sabra (Cambridge, MA, 2003), pp. 23-51 (36-39); Fritz S. Pedersen, 'Astronomical Tables for Pisa in Ms. København K.B., GkS 277, Fol.', Renaessanceforum, 3 (2007), 1-16; Pedersen, The Toledan Tables (n. 13), III, pp. 1208-1209.

${ }^{24}$ See on the background Julio Samsó, “'Dixit Abraham Iudeus': algunas observaciones sobre los textos astronómicos latinos de Abraham Ibn 'Ezra', Iberia Judaica, 4 (2012), 171-200 (177-185, 193-196); C. Philipp 
regard, they were more similar to the tables included in the astronomical treatises of Ptolemy and al-Battānī, neither of which exerted much of a direct influence on computational practice in Latin Europe. ${ }^{25}$

Ibn Ezra's tables were apparently first created in 1143 and existed in a number of adaptations to different localities such as Pisa, Lucca, Winchester, and London. ${ }^{26}$ Only the Tables for Pisa and London have survived, but the Tables of Winchester are mentioned repeatedly in an anonymous text that precedes Henry Bate's translation of a Hebrew version of al-Kindi's Liber de iudiciis revolutionum annorum mundi in one fifteenth-century

E. Nothaft, 'Criticism of Trepidation Models and Advocacy of Uniform Precession in Medieval Latin Astronomy', Archive for History of Exact Sciences, 71 (2017), 211-244.

${ }^{25}$ A noteworthy exception are the tables for the meridian of Paris (epoch: AD 1179) in MSS London, British Library, Add. 17368, fols. 28r-32v; Oxford, Bodleian Library, Savile 23, fols. $77 \mathrm{v}-86 \mathrm{r}$, which are based on Ptolemy's mean motion parameters. The same applies to the astronomical tables of Abraham bar Hiyya, which exist in a twelfth-century Latin version studied by Raymond Mercier, 'Astronomical Tables of Abraham Bar Hiyya', in Time, Astronomy, and Calendars in the Jewish Tradition, ed. Sacha Stern and Charles Burnett (Leiden: Brill, 2014), pp. 155-207 (168-180).

${ }^{26}$ For the Tables of London, see MSS London, British Library, Arundel 377, fols. $7 \mathrm{v}-35 \mathrm{r}$, and Toledo, Archivo y Biblioteca Capitulares, 98-22, fols. 104v-112r. Their tables for the mean Sun and Moon also appear in MS Oxford, Bodleian Library, Digby 114, fols. 25r-26v, where they are placed alongside the Toledan Tables and Tables of Toulouse. For the Tables of Lucca and Tables of Winchester, see Charles Burnett, “Abd al-Masīh of Winchester', in Between Demonstration and Imagination: Essays in the History of Science and Philosophy Presented to John D. North, ed. Lodi Nauta and Arjo Vanderjagt (Leiden: Brill, 1999), pp. 159-169 (163-166); Burnett, 'Latin Alphanumerical Notation, and Annotation in Italian, in the Twelfth Century: MS London, British Library, Harley, 5402', in Sic itur ad astra: Studien zur Geschichte der Mathematik und Naturwissenschaften, ed. Menso Folkerts and Richard Lorch (Wiesbaden: Harrassowitz, 2000), pp. 77-90 (78-81); John D. North, 'The Longitudes of Winchester', Cahiers de l'Institut du Moyen-Âge Grec et Latin, 73 (2002), 13-20. 
manuscript. ${ }^{27}$ The author of this text, perhaps Ibn Ezra himself, uses the Tables of Winchester for a series of calculations pertaining to the year 1067 and takes credit for their creation, also indicating that Winchester was his place of writing. ${ }^{28}$ Another witness to these tables is Henry Bate, who over several years of his career was heavily invested in rendering Abraham Ibn Ezra's astrological works into Latin. ${ }^{29}$ In an undated treatise describing a planetary equatorium, Bate is found mentioning Ibn Ezra's Tables of Pisa and the Tables of Winchester as examples of tables cast for longitudes 'in the ninth sphere', that is, for tropical

\footnotetext{
${ }^{27}$ MS Vatican, Biblioteca Apostolica Vaticana, Pal. lat. 1407, fols. 55r-58r. I thank David Juste for bringing this text to my attention. A Middle English version of it had previously been discovered by John D. North, 'Winchester 1067', Centaurus, 45 (2003), 130-141, who mistakenly concluded that the Tables of Winchester were based on the Toledan Tables.
}

${ }^{28}$ MS Vatican, Biblioteca Apostolica Vaticana, Pal. lat. 1407, fol. 57v: 'Fuitque introitus solis in caput Arietis in hoc loco, qui est Winconia, per 14 horas et 50 minuta hore post medietatem diei. [...] Et hic est locus Saturni et Iovis in hora coniunctionis eorum secundum tabulas quas ego composui'. Ibn Ezra's authorship of the Tables of Winchester is confirmed by a marginal note in a mid-thirteenth-century copy of the Toledan Tables in MS Cambridge, University Library, Kk.1.1, fol. 145v: 'Scito quod tabule mediorum cursuum solis ad meridiem Winconiensem ab Abrahamo condite precedunt has tabulas mediis cursibus 9 dierum et 12 horarum et 12 minutorum hore'.

${ }^{29}$ See most recently Shlomo Sela, 'The Ibn Ezra-Henry Bate Astrological Connection and the Three Abrahams', Mediterranea, 2 (2017), 163-186. 
longitudes. ${ }^{30} \mathrm{He}$ makes the same claim for the Tabule Machlinenses and expressly associates them with the Tables of Pisa. ${ }^{31}$

Given the strong influence Ibn Ezra is known to have exerted on Henry Bate, it would be tempting to suppose that his Tables of Mechelen, like those for Winchester, were simply another adaptation of the Tables of Pisa. ${ }^{32}$ This is not the case, however, nor is it possible to follow some recent scholars in asserting that the Tables of Mechelen were derived from the Toledan Tables. ${ }^{33}$ Indeed, this conclusion is flatly contradicted by Bate's above-cited remarks

\footnotetext{
${ }^{30}$ Opusculum Abrahe Iudei de nativitatibus cum exemplaribus figuris singulis domibus antepositis: Et magistralis compositio astrolabii Hanrici Bate (Venice: Ratdolt, 1485), sigs. d4r-v: 'Ptholemeus vero: et Geber:
} Albategni: Abrahamque Iudeus: et Açophius, ceteri quoque magistri probationum et maxime orientales astronomi motus planetarum secundum nonam speram considerantes radices suas super hoc fundaverunt: et hoc patet in tabulis Ptholomei: Albategni et Abrahe: in tabulis Pisanis, Wintoniensibus et aliis'. On Bate's equatorium, see Emmanuel Poulle, Les instruments de la théorie des planètes selon Ptolémée: équatoires et horologerie planétaire du XIII au XVIe siècle, vol. 1 (Geneva: Droz, 1980), pp. 210-213.

${ }^{31}$ Opusculum Abrahe Iudei (n. 30), sig. d4v: 'Et quamquam hoc nostrum instrumentum super octavam speram fundatum sit: nihilominus valet ad motus planetarum hac secunda via coequandos que est secundum nonam speram. Si igitur placuerit hac secunda via locum Solis invenire ex tabulis ad hoc constitutis: ut sunt tabule Machlinenses: vel Pisane'. Ibid., sig. d5r: 'Si vero libuerit opus nostrum ad secundam sectam permutare: et locum Saturni secundum illius secte radices per instrumentum nostrum equare: extrahamus centrum Saturni et argumentum ex tabulis Machlinensibus aut Pisanis vel consimilibus que secundum nonam speram currunt'. ${ }^{32}$ See, for instance, Hermann Greive, Studien zum jüdischen Neuplatonismus: Die Religionsphilosophie des Abraham Ibn Ezra (Berlin: de Gruyter, 1973), p. 46n52.

${ }^{33}$ See e.g. Poulle, Les instruments (n. 30), pp. 20-21; Boudet and Husson, 'The Earliest Astronomical Tables', 291; Giuseppe Bezza, 'Representation of the Skies and the Astrological Chart', in A Companion to Astrology in the Renaissance, ed. Brendan Dooley (Leiden: Brill, 2014), pp. 59-86 (67); C. Philipp E. Nothaft, 'Vanitas vanitatum et super omnia vanitas: The Astronomer Heinrich Selder and a Newly Discovered FourteenthCentury Critique of Astrology', Erudition and the Republic of Letters, 1 (2016), 261-304 (273-274). This 
in the Speculum divinorum, where he implies that the tables in question were at least in part the product of his own observations. The importance of this testimony was already recognized a century ago by the great Polish historian of medieval science, Aleksander Birkenmajer (1890-1967), who stressed Bate's exceptional status among the astronomers of his time,${ }^{34}$ yet subsequent scholars have failed to investigate this point further, for instance by analysing the parameters that underlie the Tabule Machlinenses. As I shall attempt to demonstrate in what follows, the two extant versions of Bate's tables employ values for planetary mean motion that are not attested in any potential source and that are indeed likely to have been derived by observational means, in harmony with his own claims. It hence appears that Bate deserves to be better known as the creator of the earliest set of astronomical tables original to the Latin Christian world-original in the sense that its parameters were not simply lifted wholesale from earlier Greek and Islamic sources, but derived afresh from empirical data. More than that, his Tables of Mechelen turn out to cast an intriguing spotlight on the final decades of the thirteenth century as a period when astronomers based in and

mistaken idea may have been aided by Pedersen, The Toledan Tables (n. 13), III, p. 1210, where the Tables of Mechelen and Tables of Pisa are lumped together with various adaptations of the Toledan Tables.

${ }^{34}$ Aleksander Birkenmajer, 'Henri Bate de Malines, astronome et philosophe du XIII' siècle' (Kraków, 1923), reprinted in idem, Etudes d'histoire des sciences et de la philosophie du Moyen Age (Kraków: Ossolineum, 1970), pp. 105-115 (115): 'En effet, à l'époque où on préférait étudier les cours des astres sur le papier que sur le ciel, le savant malinois appartient au nombre fort restreint des astronomes qui les on directement observés. Plus que cela; il se servit de ses observations pour construire des nouvelles tables astronomiques qu'il ne cessait de vérifier sur le ciel, et il les a remaniées jusqu'à trois fois pour les rendre de plus en plus précises. A ma connaissance aucun de ses contemporains n'a poussé plus loin les travaux dans le domaine de l'astronomie pratique'. 
around Paris took some valiant steps beyond written authority and towards becoming more independent and critically minded practitioners of their craft. ${ }^{35}$

\section{The two extant versions of the Tabule Machlinenses}

From the passage in the Speculum divinorum, it appears that Henry Bate's tables for the meridian of Mechelen were corrected on three separate occasions between their original creation and the eclipse of 31 January 1310. This much seems to follow from his use of the words tertio iam et ultimo correctas, ${ }^{36}$ although it is possible that Bate meant to include the original version in his count of three. All that can be said for certain about the original version is that it must have existed as early as 1280, the year in which Henry Bate began to pen his Nativitas, an astrological autobiography revolving around an extensive analysis of his own birth horoscope. To be able to carry out this analysis, Bate needed mean motion tables valid for the coordinates of his birth town, Mechelen. They also needed to be as accurate as possible, hence providing an obvious incentive for the repeated corrections Bate alluded to later in his life. The commentary on Bate's horoscope accordingly described the computational tables used as having been 'brought in line with the truth and made correct with the highest degree of examination according to the equations of Ptolemy and based on

\footnotetext{
${ }^{35}$ I shall return to this point in the conclusion below.

${ }^{36}$ See $\mathrm{n} .12$ above for the quotation. A similar qualifier, ultimo verificatas, which was probably supposed to mean 'brought in line with the truth to the highest degree', appeared in Bate's lost commentary on Albumasar's De magnis coniunctionibus, which is still known from fragments preserved in Pierre d'Ailly's Elucidarium astronomice concordie cum theologica et historica veritate (1414). See Pierre d'Ailly, Tractatus de imagine mundi et varia ejusdem auctoris et Joannis Gersonis opuscula (Leuven: Johannes de Westfalia, c. 1480-1483), sig. ee1r-v (ch. 1): 'Inveni per tabulas Machlinienses ultimo verificatas annum coniunctionis significantis diluvium 3382 annis ante annum incarnationis dominice'.
} 
his observations and ours'. ${ }^{37}$ Of the three or four different recensions of the Tabule Machlinenses that must have existed at one point, only two have been identified so far in the manuscripts. In what follows, I shall introduce these recensions as Versions A and B.

\section{Version $A$}

Version $A$ is attested in MS Cusanus $210=$ Bernkastel-Kues, Cusanusstiftsbibliothek, 210, fols. $84 \mathrm{v}-87 \mathrm{r}$ (s. XIV [before 1371]) and MS Paris $7421=$ Paris, Bibliothèque nationale de France, lat. 7421, fols. 211r-220r (s. XIII/XIV). ${ }^{38}$ The earlier of these two copies, MS Paris 7421, offers a full set of mean motion tables covering all seven planets. Each motion is represent by six sub-tables, which together cover a full leaf in the manuscript: (i) collectedyear radices for 120, 560, 980, 1200 completed Julian years, followed by steps of 20 up to 1460 (1480 in the case of Jupiter); (ii) expanded years from 1 to 20 , of which years $3,7,11$, 15, and 19 are leap years; (iii) Julian months from March to February; (iv) days; (v) hours; (vi) minutes. The headings for some motions (Sun, Moon, lunar anomaly, Saturn) proclaim that the time difference between Mechelen and 'Ptolemy's Alexandria' (Alexandria Ptholomei) is 1;30h. The copy in MS Cusanus 210 remains incomplete and arranges the material differently, starting with two tables combining the collected-year radices for (i) Sun,

\footnotetext{
${ }^{37}$ Henry Bate, Nativitas, 11. 347-352, ed. Steel et al. (n. 1): 'Ponamus igitur in nomine Domini figuram nativitatis servi Dei gloriosi secundum longitudinem et latitudinem opidi Machliniensis iuxta tabulas ascensionum eiusdem loci necnon et loca planetarum super eundem locum ultima examinatione verificata et correcta secundum equationes Ptolomei et super observationes suas et nostras'.

${ }^{38}$ For descriptions see Jakob Marx, Verzeichnis der Handschriften-Sammlung des Hospitals zu Cues (Trier: Schaar \& Dathe, 1905), pp. 201-202; Pedersen, The Toledan Tables (n. 13), I, pp. 94-95, 161; David Juste, Les manuscrits astrologiques latins conservés à la Bibliothèque nationale de France à Paris (Paris: CNRS éditions, 2015), p. 151.
} 
Moon, lunar anomaly and (ii) the superior planets. This is followed by expanded-year tables for the same six motions as well as the corresponding tables for months. At the end, there is a single collected-year table for Venus, but no further tables for Mercury or the lunar nodes. ${ }^{39}$ Also, the copy gives no indication that the mean motions were calculated for the meridian of Mechelen.

In structural terms, the mean motion tables attested in these two manuscripts are very clearly related to the Tables of Pisa and their adaptations to other meridians. This is true in particular for MS Paris 7421, as Ibn Ezra used the same division of each mean motion into six sub-tables, to the extent that the values in elements (v) and (vi) of MS Paris 7421 are often the same as those in the Tables of Pisa and London. ${ }^{40}$ Another shared trait is the use of cycles of 20 Julian years for the tables of expanded and collected years, although Henry Bate chose a completely different set of epoch dates compared to his predecessor. The collected years in Ibn Ezra's tables originally set in with 1029 years from the beginning of the Christian era, ${ }^{41}$ whereas the Tables of Mechelen start with 120 years, but only advance by regular steps of 20 years from 1200 onward. In MS Paris 7421, the connection to Ibn Ezra is strengthened considerably by the occurrence of a second batch of tables for Mercury, which this time only consists of sub-tables (i) and (ii). They are headed Argumentum Mercurii

\footnotetext{
${ }^{39}$ A later hand filled in the blank space on the final page of the quire (fol. $87 \mathrm{v}$ ) with tables for the excess of revolution excerpted from the Alfonsine Tables, adding to them an epoch value for the vernal equinox in AD 1371. This probably provides a solid terminus ante quem for the preceding copy of the Tables of Mechelen. ${ }^{40}$ For the Tables of Pisa, see, e.g., MSS Paris, Bibliothèque nationale de France, lat. 16207, fols. 20v-36r; Paris, Bibliothèque nationale de France, lat. 16208, fol. 4r-v; Oxford, Bodleian Library, Selden supra 90, fols. 30r34r. For the Tables of London, see the copies listed in n. 26 above.

${ }^{41}$ This is attested in an anonymous mid-twelfth-century work on the Tables of Pisa starting 'Ptolemaeus et multi sapientium...'. See MS Cambridge, Fitzwilliam Museum, McClean 165, fol. 70r, 71r. In the preserved copies, however, the starting point is moved to 1169 completed years. See Mercier, 'The Lost Zīj' (n. 23), pp. 2-3, 16.
} 
secundum Abraham Evenzare [sic] in annis Christi ad meridiem Machlinie (fol. 220r) and display the same progress of $14 ; 28,50^{\circ}$ in 20 Julian years as do the Tables of Pisa and London. As we shall see below, the parameter for Mercury's mean anomaly that Bate employed in his main table instead gave a surplus of $14 ; 26,11^{\circ}$, which was derived from Ptolemy's Almagest.

\section{Version B}

The other preserved version of the Tables of Mechelen survives only in a single manuscript, MS Paris 3091 = Paris, Bibliothèque nationale de France, n.a.1. 3091, fols. 79v-80v (s. $\left.\mathrm{XIII}{ }^{\mathrm{ex}}\right){ }^{42}$ The mean motion tables are here reduced to elements (i) to (iii) and the sequence of collected years stops at 1320 , which is exactly $60 \times 20=1200$ years after the radix. As in Version A, each entry in these tables is divided into four columns, for signs, degrees, minutes, and seconds. In the case of some extended-year tables, however, the final line has additional numbers in the right margin that serve to render the 20 -year increment of the corresponding mean motion more precise. In the case of the Sun, Moon, and Mars, the scribe merely added a number for sexagesimal thirds, which could have easily been inferred from the 1200 -year increment in the collected-year table (since $1200=60 \times 20$ ). A more interesting case are the tables for Saturn and Venus, where the 20 -year values receive an

\footnotetext{
${ }^{42}$ The existence of this manuscript was first noted by Marie-Thérèse d'Alverny, 'Un nouveau manuscrit des “Tabulae Mechlinenses” d'Henri Bate de Malines', in Actes du VIII Congrès international d'histoire des sciences, Florence-Milan 3-9 septembre 1956, vol. 1 (Vinci: Grupo italiano di storia delle scienze, 1958), pp. 355-358. See also Pedersen, The Toledan Tables (n. 13), I, pp. 169-170; David Juste, 'MS Paris, Bibliothèque nationale de France, n.a.1. 3091' (update: 10.02.2018), Ptolemaeus Arabus et Latinus. Manuscripts, URL $=$ http://ptolemaeus.badw.de/ms/535 [accessed 26 October 2018]; Juste, Les manuscrits astrologiques (n. 38), pp. 270-271.
} 
extension to the fourth sexagesimal place. This presumably reflects some deeper knowledge about the underlying parameter and hence points to Henry Bate as the author of these additions.

The tables in MS Paris 3091 are introduced by a general heading, which gives the longitude of Mechelen as 47;45 'from the West' (ab occidente), adding that this was approximately the same position as that of Toulouse (eadem scilicet fere cum longitudine Tholose). The northern latitude of Mechelen is given as $51 ; 12^{\circ}$, which is only $0 ; 11^{\circ}$ above the modern value $\left(51 ; 1^{\circ}\right) \cdot{ }^{43}$ As for the longitudinal value $47 ; 45^{\circ}$, it may be that the expression $a b$ occidente was meant to refer to the Mechelen's distance from the western prime meridian, which was located $28 ; 30^{\circ}$ west of Toledo. ${ }^{44}$ In that case the author of this heading would have imagined Mechelen to lie $19 ; 15^{\circ}$ further east than Toledo-a grossly exaggerated value. A different interpretation suggests itself if one compares MS Paris 3091 with the heading of the Tables of Toulouse in a thirteenth-century manuscript owned by Bate's contemporary Peter of Limoges. The position of Toulouse is here given as $50^{\circ}$ ab Arin in occidente, which is to say $50^{\circ}$ west of Ujjain (India), a reference point thought to lie in the middle of the world, at $90^{\circ}$ from the western and the eastern prime meridians. By implication, Toulouse is here claimed to lie $40^{\circ}$ east of the western prime meridian and $11 ; 30^{\circ}$ east of Toledo, as is indeed

\footnotetext{
${ }^{43}$ MS Paris, Bibliothèque nationale de France, n.a.1. 3091, fol. 79v: 'Medius motus planetarum ad meridiem Machline, cuius longitudo est ab occidente 47 graduum, 45 minutorum, eadem scilicet fere cum longitudo Tholose. Latitudo vero 51 gradus et 12 minuta. Et sunt ad annos Christi'. Bate had assumed the same latitude in 1274 when writing his Magistralis compositio astrolabii. See the editions of this text in Opusculum Abrahe Iudei (n. 30), c5v, and Robert T. Gunther, The Astrolabes of the World, 2 vols. (Oxford: Oxford University Press, 1932), 2:368.

${ }^{44}$ See Mercè Comes, 'The 'Meridian of Water' in the Tables of Geographical Coordinates of al-Andalus and North Africa', Journal for the History of Arabic Science, 10 (1992-1994), 41-51.
} 
confirmed in the margin of the same manuscript page. ${ }^{45}$ If the expression $a b$ occidente in MS Paris 3091 was simply a contraction of ab Arin in occidente, then the longitude of Mechelen would come to lie $90^{\circ}-47 ; 45^{\circ}-28 ; 30^{\circ}=13 ; 45^{\circ}$ east of Toledo and only $13 ; 45^{\circ}-11 ; 30^{\circ}=$ $2 ; 15^{\circ}$ east of Toulouse. This result is more in line with the abovementioned claim that Toulouse and Mechelen are relatively close to each other and with the fact that the actual longitude difference between the two cities is $4 ; 28^{\circ}-1 ; 26,38^{\circ}=3 ; 1,22^{\circ}$.

On the final page of the extant copy of Version B (fol. 80v), one finds some additional tables not included in Version A, which deal with planetary apogees and the annual excess of revolution. These are accompanied by a few paragraphs of text that start with some general remarks about the differences between the Tables of Mechelen and the Toledan Tables commonly in use. ${ }^{46}$ The author of these paragraphs, probably Henry Bate himself, acknowledges that there are other tables for the meridian of Mechelen in circulation, but claims that 'these are false and have been made a long time ago. But the ones here were recently corrected by observations carried out with instruments, although they still deviate in the case of Mars'. ${ }^{47}$ As we shall see below, Version B's entries for Mars, but also those for Jupiter, Saturn, and Venus, differ significantly from those found in Version A.

\footnotetext{
${ }^{45}$ MS Paris, Bibliothèque nationale de France, lat. 16658, fol. 70r: 'Medius cursus solis ad annos Christi solares ad medium diem civitatis Tolose. Latitudo est 42 graduum et 45 minutorum. Et distat ab Arin in occidente 50 gra $<$ dibus $>$. [Added in margin:] Et a Tolete in oriente 11 gra $<$ dibus $>$ et 30 minutis'. See Poulle, 'Un témoin' (n. 19), p. 63; Pedersen, 'The Toulouse Tables' (n. 19), p. 11; Juste, Les manuscrits astrologiques (n. 38), p. 243. ${ }^{46}$ See n. 55 below.

${ }^{47}$ MS Paris, Bibliothèque nationale de France, n.a.1. 3091, fol. 80v: 'Et nota quod alie sunt tabule mediorum motuum ad meridiem $\mathrm{Mach}<\mathrm{li}>$ nie que sunt false et diu est facte. Sed iste nuper correcte sunt per observationes instrumentorum; tamen in istis adhuc differentii est de Marte'.
} 


\section{Attested uses}

Precise planetary longitudes calculated on the basis of the Tables of Mechelen have so far been found in three sources, two of which were the subject of a detailed study published by Emmanuel Poulle in $1964 .{ }^{48}$ The first is Henry Bate's own Nativitas, for which Poulle came to the tentative conclusion that the computational results depended on neither Version A nor Version $\mathrm{B}$, but on a third version now lost. ${ }^{49}$ It is worth noting, however, that there is a perfect match between the Nativitas and Version A in the case of Saturn and that this version provides a significantly closer fit for Jupiter, Mars, and Venus than does Version B. ${ }^{50} \mathrm{~A}$ discrepancy that exceeds a full degree is reached only for the mean anomaly of Mercury, where Bate records a mean longitude of $1 \mathrm{~s} 1 ; 25,33^{\circ}$ at the time of his birth (24 March 1246, 00:06 a.m.) compared to a longitude of 0 s $27 ; 31,6^{\circ}$ yielded by both known versions of the Tables of Mechelen. Yet here we should take into account that Version A also contains alternative tables for Mercury cast 'according to Abraham Ibn Ezra', the entries in which would raise the result to $1 \mathrm{~s} 1 ; 26,8^{\circ}$.

\footnotetext{
${ }^{48}$ Emmanuel Poulle, 'Astrologie et tables astronomiques au XIII ${ }^{\mathrm{e}}$ siècle: Robert le Febvre et les Tables de Malines', Bulletin philologique et historique (jusqu'à 1610) du Comité des travaux historiques et scientifiques (1964), pp. 793-831, repr. as ch. 7 in idem, Astronomie planétaire au Moyen Âge latin (Aldershot: Variorum, 1996). Poulle made no apparent effort to analyse the parameters underlying the Tables of Mechelen.

${ }^{49}$ Poulle, 'Astrologie' (n. 48), p. 804.

${ }^{50}$ See the data presented in Poulle, 'Astrologie' (n. 48), pp. 807-810. An exception of sorts is the copy of the Nativitas in MS Segovia, Archivo y Biblioteca de la Catedral, B349 (84), fol. 4r, which features two different values for the mean longitudes of Saturn and Jupiter. The second of these was calculated using Version B.
} 
A simpler story is told by our second source, which happens to be another autobiographical Nativitas, this time written in 1285 by someone born in $1255 .{ }^{51}$ The mean longitudes listed in this text can be recomputed using Version A (as found in MS Paris 7421) with a relatively high rate of success, which should be enough to take 1285 as a terminus ad quem for the creation of Version A. Moreover, the comparatively weaker congruity between Version A and the longitudes listed in the Nativitas of Henry Bate may be a sign that this particular version of the tables did not yet exist in 1280. Under these circumstances, it seems justified to infer that Bate drew up Version A at some point during the half-decade from 1280 to 1285 , which would place it relatively early on a timeline that extends from the Nativitas to his testimony relating to the eclipse of 1310 . Version B is almost certainly the later of the two.

The third source to attest to the practical use of the Tabule Machlinenses was discovered recently by David Juste. ${ }^{52}$ It documents an unidentified astronomer's attempt to verify the planetary positions contained in Ali Ibn Ridwān's nativity horoscope for the beginning of 15 January AD 988, which is itself part of an appendix Ibn Ridwān (known in Latin as Haly Abenrudian) added to his commentary on Ptolemy's Quadripartitum. Numerous copies of the Quadripartitum going back to the late thirteenth century follow this appendix up with a note in which an anonymous author declares his intention of using the Tables of Mechelen to determine whether Ibn Ridwān cast his horoscope for the eighth or

\footnotetext{
${ }^{51}$ Poulle, 'Astrologie' (n. 48), pp. 794-795, identified the author as Robert Le Febvre, physician to King Philip IV, but David Juste has recently shown that there is a more plausible candidate in William of Saint-Cloud. See David Juste, 'Bate's Nativitas in Context', ch. 5 in Steel et al., The Astrological Biography (n. 1). I am grateful to Dr Juste for sharing this material with me before publication.

${ }^{52}$ See the section on William of Saint-Cloud (5.3.4) in Juste, 'Bate's Nativitas' (n. 51).
} 
ninth sphere. ${ }^{53}$ Only one of these copies, however, preserves the actual results of his calculations: MS Oxford, New College, 282, fols. 197r-198r, which dates from $1423 .^{54}$

An attempt to recalculate the mean longitudes recorded in this manuscript will produce a perfect match with Version A in the case of the Sun and the three superior planets (see Table 1). For the mean lunar anomaly and the anomaly of Mercury the agreement with Version A is still close enough to suggest a scribal or reckoning error on the part of the calculator. Problems are caused by the mean longitude of the Moon and the mean anomaly of Venus, where the results noted by the calculator are closer to the those obtainable with Version B. In the case of the Moon, Version B's 7s $12 ; 45,26^{\circ}$ looks similar to the calculator's $7 \mathrm{~s} 12 ; 45,6^{\circ}$, but here it must be emphasized that the collected-year table in MS Paris 3091 is corrupt in several places. If it is corrected based on the 20 -year increment in the table of expanded years, the result changes to $7 \mathrm{~s} 12 ; \underline{46}, 26^{\circ}$. In the case of Venus, Version B would supply us with $9 \mathrm{~s} 2 ; 1,28^{\circ}$, which is the result of combining the entries for 980 years $(5 \mathrm{~s}$ $\left.13 ; 55,54^{\circ}\right), 6$ years $\left(9 \mathrm{~s} 0 ; 48,17^{\circ}\right), 10$ months $\left(6 \mathrm{~s} 8 ; 39,24^{\circ}\right)$, and 14 days $\left(8 ; 37,53^{\circ}\right)$. Now, adding up just the minutes and seconds of these four values will yield 179 minutes and 148 seconds or $3 ; 1,28^{\circ}$, but if the calculator overlooked the fact that two full minutes accrue from

\footnotetext{
${ }^{53}$ See, e.g., MS Vienna, Österreichische Nationalbibliothek, 2311, fol. 95rb (s. XIII' ${ }^{\text {ex }}$ ): 'Volui probare utrum iste actor iudicaret secundum nonam speram vel secundum octavam. Et inveni per loca planetarum que ponit in figura sue nativitatis quod ipsa fuit annis Christi perfectis 986, 10 mensibus, 15 die Ianuarii, qua die equavi planetas secundum tabulas Math $<$ linienses $>[$ sic $]$ et inveni sic'. The calendrical year in the Tables of Mechelen begins in March, so 986 completed years of the Christian era +10 completed months point to a date in January
} AD 988 .

${ }^{54}$ See David Juste, 'MS Oxford, New College, 282' (update: 24.10.2018), Ptolemaeus Arabus et Latinus. Manuscripts, URL = http://ptolemaeus.badw.de/ms/260 [accessed 26 October 2018]. According to David Juste (see n. 52), the author of these calculations was identical with the author of the Nativitas of 1285, and hence with William of Saint-Cloud. 
the seconds, he would have put down $2 ; 59,28^{\circ}$. This would be enough to explain the value recorded in the New College manuscript, which is $9 \mathrm{~s} 29^{\circ}+2 ; 59,28^{\circ}=9 \mathrm{~s} 1 ; 59,28^{\circ}$ instead of $9 \mathrm{~s} 29^{\circ}+3 ; 1,28^{\circ}=9 \mathrm{~s} 2 ; 1,28^{\circ}$. Perhaps, then, this may be taken as a sign that the calculator used a version of the Tables of Mechelen that was a hybrid between Versions A and B.

$<$ Table 1 here $>$

\section{Apogeal longitudes and precession}

Like Ibn Ezra's tables for the meridian of Pisa, those produced by Henry Bate displayed longitudes in the ninth sphere, rather than the eighth, and assumed a beginning of the day at noon of the current calendrical date, rather than the previous one. ${ }^{55}$ The decision to use the ninth sphere as a frame of reference would have required Bate to include in his tables a list of epoch values for the apogees of the Sun and the five planets as well as some instructions on how to determine their increase over time, as knowing the position of the apogee was a prerequisite for calculating a planet's true longitude. Tables for this very purpose do indeed appear at the end of Version B, where Bate explicitly states that the apogeal longitudes increase by 51 seconds every year. ${ }^{56}$ On closer inspection, however, the entries in the

\footnotetext{
55 This is acknowledged in the text accompanying Version B. See MS Paris, Bibliothèque nationale de France, n.a.1. 3091, fol. 80v: 'Nota quod ad inveniendum medium cursum planete per istas tabulas intratur cum annis Christi, mensibus et diebus et etiam horas preteritis et accipitur quod invenitur in directo, sicut fit in tabulis Tholetanis. Sed differentia est in hoc quia iste tabule supponunt quod dies incipiat in medio sui et finiatur in medio sequentis et Tholetane suppont quod incipiat in medio precedentis et finiatur in medio sui. Item differentia est quia per istas tabulas habetur medius motus in nona spera, ita quod in fine equationis non oportet addere motus octave spere. Sed per Tholetanas habetur medius motus in octava spera tantum'.

${ }^{56}$ MS Paris, Bibliothèque nationale de France, n.a.1. 3091, fol. 80v: 'Item nota quod auges scribuntur hic in nona spera, sicut et medii motus. Aliter non haberetur centrum planete et oportet auges mutari, quia moventur in nona
} 
corresponding tables turn out to have been calculated using a more precise value. The table for the solar apogee, for instance, adds 2 s $29 ; 32,54^{\circ}-2 \mathrm{~s} 13 ; 1,16^{\circ}=16 ; 31,38^{\circ}$ over the 1157 years from $\mathrm{AD} 138$ to 1295 . This makes for an average increase $0 ; 0,51,25,27 \ldots{ }^{\circ}$ per year, suggesting that Bate intended to operate with a precession rate of $1^{\circ}$ every 70 years $(=$ $0 ; 0,51,25,42 \ldots{ }^{\circ}$ per year), as he also did in his treatise on the equatorium. ${ }^{57}$

As far as we know, this rather accurate value was first transmitted to the Latin West by Abraham Ibn Ezra, who attributed it to his predecessor al-Șūfī. ${ }^{58}$ An example of its application appears in the aforementioned text based on the Tables of Winchester, where Ibn Ezra (or whoever wrote the text in question) assumes that the solar apogee moved $0 ; 28^{\circ}$ between 1067 and $1100 .{ }^{59}$ The apogeal longitude for 1100 is here given as $2 \mathrm{~s} 26 ; 14^{\circ}$, which happens to agree well with the information provided in a mid-thirteenth century recension of

spera secundum motum octave spere. Unde pro quolibet anno oportet addere augibus 51 secunda nisi ad illum annum scribantur in tabula'.

${ }^{57}$ Opusculum Abrahe Iudei (n. 30), sig. d4v: 'Est etiam advertendum quia movetur octava spera secundum posteros magistros probationum uniformiter in 70 annis gradu uno. Et hunc motum sequuntur auges planetarum quare secundum exigentiam temporis rectificantur he auges relate ad speram nonam: et hoc pro quibuslibet 70 annis in gradu uno: et pro centum in gradu uno et 25 minutis: et pro 20 annis in 17 minutis: et pro anno uno in 51 secundis'.

${ }^{58}$ See the edition of Ibn Ezra's Liber de rationibus tabularum in José María Millás Vallicrosa, El libro de los fundamentos de las Tablas astronómicas de R. Abraham Ibn 'Ezra (Madrid: CSIC, 1947), p. 78. Bate cites this text in Speculum XXII.17, ed. Steel and Guldentops (n. 3), p. 337, and mentions it in the preface to his translation of Ibn Ezra's De mundo. See also Bate, Speculum XXII.5, ed. Steel and Guldentops (n. 3), p. 283, where Bate attributes the precession rate of 1\%/70y to Abraham [Ibn Ezra] and al-Șūfì. Other attestations are noted in Pedersen, The Toledan Tables (n. 13), III, pp. 1226-1227; Nothaft, 'Criticism of Trepidation Models' (n. 24), p. 223.

${ }^{59}$ MS Vatican, Biblioteca Apostolica Vaticana, Pal. lat. 1407, fol. 57v. 
the Tables of Pisa made in Paris. According to the latter, the longitude of the apogee of each planet increases by 51 seconds per year and the solar apogee was at $2 \mathrm{~s} 28,20^{\circ}$ in the year 1248. This makes for an increase of $2 ; 6^{\circ}$ over $1248-1100=148$ years, well in line with the fact that $148 \times 0 ; 0,51^{\circ}=2 ; 5,48^{\circ} .{ }^{60}$ By contrast, Bate's tables put the apogee at the end of $\mathrm{AD}$ 1285 at $2 \mathrm{~s} 29 ; 24,22^{\circ}$, which $1 ; 4,22^{\circ}$ more than what the Paris recension of the Pisan tables gives for 1248 . Based on an annual precession rate of $0 ; 0,51^{\circ}$ the apogeal longitudes should have increased by no more than $0 ; 0,51^{\circ} \times 37=0 ; 31,27^{\circ}$ between 1248 and 1285 .

It remains unclear how Bate determined the epoch values for his apogee tables, which for some reason all place their radix 26 years before the incarnation, followed by an entry for 138 years after the incarnation. What we can say with some confidence is that Bate already had them in use when calculating his Nativitas in $c .1280 .{ }^{61}$ The apogeal longitudes listed there can all be derived by adding a constant of $9 ; 38,35^{\circ}$ to the entry in the third line of the corresponding apogee table in MS Paris 3091, which gives the apogeal longitude 570 years after the start of the Christian era:

$\begin{array}{ll}\text { Sun/Venus: } & \text { 2s } 19 ; 11,34^{\circ}+9 ; 38,35^{\circ}=2 \text { s } 28 ; 50,9^{\circ} \\ \text { Saturn: } & \text { ss } 2 ; 8,34^{\circ}+9 ; 38,35^{\circ}=8 \text { s } 11 ; 47,9^{\circ} \\ \text { Jupiter: } & \text { 5s } 14 ; 23,34^{\circ}+9 ; 38,35^{\circ}=5 \text { s } 24 ; 2,9^{\circ} \\ \text { Mars: } & 4 s 3 ; 14,34^{\circ}+9 ; 38,35^{\circ}=4 \text { s } 14 ; 53,9^{\circ} \\ \text { Mercury: } & \text { 6s } 17 ; 6,34^{\circ}+9 ; 38,35^{\circ}=6 \text { s } 26 ; 45,9^{\circ}\end{array}$

\footnotetext{
${ }^{60}$ MS Copenhagen, Det Kongelige Bibliotek, GkS $2772^{\circ}$, fol. 192vb: 'A medio motu planete subtrahe augem eius, qui aux crescit omni anno 51 secundis. Anno autem domini $\mathrm{M}^{\circ} \mathrm{CCXLVIII} \mathrm{fuit} \mathrm{aux} \mathrm{solis} 2$ signa, 28 minuta, 20 secunda'. See Pedersen, 'The Astronomical Tables' (n. 23), p. 2.

${ }^{61}$ MSS Paris, Bibliothèque nationale de France, lat. 7324, fol. 28ra; Paris, Bibliothèque nationale de France, and lat. 10270 , fol. $144 \mathrm{r}$.
} 
Bate used these apogeal values to calculate the horoscope for his nativity on 24 March 1246, which is a date close to the beginning of the calendar year assumed in his tables (1 March to 28 February). It is therefore likely that he would have sought the apogeal value not for 1246 , but for 1245 completed years of the Christian year. In that case, the aforementioned addition of $9 ; 38,35^{\circ}$ would be exactly congruent with an annual precession of $9 ; 38,35^{\circ} \div 675=$ $0 ; 0,51,25,46,40^{\circ}$, which amounts to $1^{\circ}$ in 69 years +364.72 days, or very nearly $1^{\circ}$ in 70 years. The same precession rate would suffice to explain the apogeal longitudes listed as part of the astronomical commentary on Ibn Ridwān's nativity, ${ }^{62}$ whose authors appears to have used a more recent recension of the Tables of Mechelen than Bate did in c.1280. Apogeal longitudes are here given to the nearest minute rather than second of arc. Also, unlike Bate, the anonymous astrologer was working with a date in January, which is close to the end of the year in the Tables of Mechelen. This would have justified including the year AD 987 in the calculation and, hence, adding $5 ; 57,26^{\circ}$ for a 417 -year interval from 570 to 987 $\left(0 ; 0,51,25,46,40^{\circ} \times 417=5 ; 57,26,9,20^{\circ}\right)$. If one applies this constant to the epoch values in Bate's tables, the results are identical to those given in the text in all cases except for Mars:

$\begin{array}{ll}\text { Sun/Venus: } & \text { 2s } 19 ; 11,34^{\circ}+5 ; 57,26^{\circ}=2 \mathrm{~s} 25 ; 9^{\circ} \\ \text { Saturn: } & 8 \mathrm{~s} 2 ; 8,34^{\circ}+5 ; 57,26^{\circ}=8 \mathrm{~s} 8 ; 6^{\circ} \\ \text { Jupiter: } & 5 \mathrm{~s} 14 ; 23,34^{\circ}+5 ; 57,26^{\circ}=5 \mathrm{~s} 20 ; 21^{\circ} \\ \text { Mars: } & 4 \mathrm{~s} 3 ; 14,34^{\circ}+5 ; 57,26^{\circ}=4 \mathrm{~s} 9 ; 12^{\circ}\left[\text { text: } 4 ; 9,16^{\circ}\right] \\ \text { Mercury: } & 6 \mathrm{~s} 17 ; 6,34^{\circ}+5 ; 57,26^{\circ}=6 \mathrm{~s} 23 ; 4^{\circ}\end{array}$

${ }^{62}$ MS Oxford, New College, 282, fol. 197v. 


\section{Bate's value for the tropical year}

Another element of the Tables of Mechelen that presumably remained stable across different recensions is the mean motion rate of the Sun. This much may be inferred from the fact that Bate, in his Nativitas, gives a mean solar longitude at his time of birth that is only $0 ; 0,30^{\circ}$ below what can be computed from Versions A and B, despite the fact that Bate appears to have used neither of those. ${ }^{63}$ Such stability is not particularly surprising given the importance of the parameter in question. The Sun's mean motion reflects an assumed length of the tropical year, which is the most fundamental parameter in all of Ptolemaic astronomy, as it enters into the determination of all other planetary motions. ${ }^{64}$ At $365 ; 14,48 d=365 d 5 ; 55,12 \mathrm{~h}$ $=3651 / 4-1 / 300$ days, Ptolemy's value exceeded the mean tropical year of $c .365 \mathrm{~d} 5 ; 48,45 \mathrm{~h}$ (modern value) by approximately $61 / 2$ minutes. One of several Islamic efforts to improve upon this value was made in the ninth century by al-Battānī, who ended up underestimating the length of the tropical year by slightly less than $21 / 2$ minutes, giving it as $365 ; 14,26 \mathrm{~d}=$ $365 \mathrm{~d} 5 ; 46,24 \mathrm{~h}=3651 / 4-3.4 / 360 \approx 3651 / 4-1 / 106$ days. ${ }^{65}$ By far the most accurate value that Latin astronomers in Henry Bate's day had available to them was the one implicit in the Tables of Pisa, which attributed to the mean Sun 20 full revolutions $+0 ; 9^{\circ}$ in 20 Julian years $(=7305 \mathrm{~d})$. This corresponds to a tropical year of $365 ; 14,32,36,24 \ldots \mathrm{d}=365 \mathrm{~d} 5 ; 49,2,33 \ldots$ or approximately $3651 / 4-1 / 131$ days.

\footnotetext{
${ }^{63}$ Poulle, 'Astrologie’ (n. 48), p. 805.

${ }^{64}$ Olaf Pedersen, A Survey of the Almagest, with annotation and new commentary by Alexander Jones (New York: Springer, 2011), p. 123.

${ }^{65}$ al-Battānī, De scientia stellarum, trans. Plato of Tivoli (Nuremberg: Petreius, 1537), fols. 27v, 80v (ch. 27, 51).
} 
Bate would have had an opportunity to read about these and other historical estimates in Abraham Ibn Ezra's Liber de rationibus tabularum, ${ }^{66}$ a work written in 1154 to accompany the Tables of Pisa. He could find them mentioned, moreover, in Ibn Ezra's Book of the World (Sefer ha-'Olam), ${ }^{67}$ which Bate translated into Latin (via a French intermediary) in $1281 .^{68}$ The latter text is particularly interesting for the way it emphasized the great confusion and uncertainty surrounding the length of the tropical year ('[n]obody can know the true length of the solar year'), ${ }^{69}$ while at the same time providing some valuable instructions as to how an adequate approximation might be derived (see below). That Henry Bate read these passages attentively is evident from his translator's preface to the Book of the World, in which he criticizes Ibn Ezra for misrepresenting Ptolemy by making him look like a sceptic about the possibility of casting the horoscope for the moment of the vernal equinox (the so-called 'revolution of the year') ${ }^{70}$ In response to Ibn Ezra's discouraging comments on the length of the solar year, Bate argued that even though past astronomers had achieved different results, it should in principle be possible to get closer to the truth by interpolating between divergent estimates. Ibn Ezra's own endorsement of a tropical year of 365 1/4 -

\footnotetext{
${ }^{66}$ Millás Vallicrosa, El libro (n. 58), pp. 75-76, 82-83.

${ }^{67}$ Abraham Ibn Ezra, Book of the World, first version, §17, ed. and trans. Shlomo Sela (Leiden: Brill, 2010), p.
} 63.

${ }^{68}$ The earliest known copy of this translation (De mundo vel seculo) happens to be in MS Paris, Bibliothèque nationale de France, n.a.1. 3091, fols. 107vb-113rb, the only manuscript to contain Version B of the Tables of Mechelen.

${ }^{69}$ Abraham Ibn Ezra, Book of the World, first version, §13.2, trans. Sela (n. 67), p. 59.

${ }^{70}$ Carlos Steel, ‘A Discussion on Ptolemy’s Authority: Henry Bate’s Prologue to his Translation of Ibn Ezra's Book of the World', in Ptolemy's Science of the Stars in the Middle Ages, ed. David Juste, Benno van Dalen, Dag Nikolaus Hasse, and Charles Burnett (Turnhout, forthcoming). 
1/131 days seemed like an apt case in point, as it was located somewhere between the short year length of al-Battānī (365 1/4 - 1/106 days) and Ptolemy’s exaggerated one (365 1/4 1/300 days). Bate acknowledged that al-Battānī had come closer to the truth than Ptolemy and that the slightly slower solar motion postulated by al-Ṣūfĩ and Ibn Ezra (i.e., 365 1/4 1/131 days) made for an even better approximation. ${ }^{71}$ Yet there was room for further improvement, as the optimal value had to be found somewhere between al-Battānī and alȘūfi/Ibn Ezra. Bate even alluded to having established such a value himself, claiming that he, in his own times

by saving to a sufficient degree the observations of Ptolemy, al-Battānī as well as our own, we have proposed a motion that is close to the mean between al-Battāni and Ibn Ezra, so that this way we may come closer to the middle, where the truth lies. ${ }^{72}$

Bate's preface never spells out the rate of motion he has in mind, although it is clear that it must lie somewhere between al-Battānī’s $0 ; 59,8,20,46,56,14 \%$ d and the $0 ; 59,8,19,42,45,5^{\circ} / \mathrm{d}$ implicit in the Tables of Pisa. As one might expect, the answer to our conundrum is provided by the Tables of Mechelen and their sub-tables for the Sun's annual mean motion:

$<$ Table 2a here $>$

$<$ Table $2 b$ here $>$

\footnotetext{
${ }^{71}$ MS Paris, Bibliothèque nationale de France, n.a.1. 3091, fol. 108ra: 'Ptholomeus enim velociores motus posuit quam Abrachis, motus tamen Ptholomei a debita velocitate defecerunt: Albategni vero motum posuit nimis velocem propinquiorem tamen veritati ex parte quam Ptholomeus. Alzophi quidem et Abraham Auenesre motus posuerunt aliquantulum tardiores Albategni ac deficientes paululum a velocitate debita'.

${ }^{72}$ Ibid.: 'Denique nostris temporibus observationes Ptholomei, Albategni necnon et nostras satis convenienter salvantes motum posuimus proportionis fere medie inter Albategni et Avenesre, ut sic ad medium in quo consistit veritas propinquius pertingamus'.
} 
As seen from Table 2a, the expanded-year table included in both recensions indicates that the Sun over 20 Julian years manages to complete 20 full revolutions $+0 ; 10,33^{\circ}$. This implies a daily motion of $7200 ; 10,33^{\circ} \div 7305=0 ; 59,8,20,28,34,59 \ldots \%$ d. A more precise value can be gleaned from the collected-year table represented by Table $2 \mathrm{~b}$, which adds $10 ; 33,19^{\circ}$ over 1200 years, implying an increase of $0 ; 10,33,19^{\circ}$ per 20 -year period. This is confirmed by an addition in the right margin of the expanded-year table in Version B, which adds tertia 19 to the value given in the final line. It would follow from this more precise value that Bate operated with a daily mean motion of $7200 ; 10,33,19^{\circ} \div 7305=0 ; 59,8,20,28,44,21 \ldots \%$ d and a tropical year of $1 \div 0 ; 59,8,20,28,44,21 \ldots \% / d=365 ; 14,27,52,23 \ldots \mathrm{d}=365 \mathrm{~d} 5 ; 47,8,57,20 \ldots h$, which is very nearly the same as $3651 / 4-1 / 112$ days (=365.241071...d).

The first remark that seems worth making about this numerical value is that Bate could not have derived it simply by taking the middle between the aforementioned solar motions of al-Battānī and Ibn Ezra. The latter is found at $\left(0 ; 59,8,20,46,56,14^{\circ} / \mathrm{d}+\right.$ $\left.0 ; 59,8,19,42,45,5^{\circ} / \mathrm{d}\right) \div 2=0 ; 59,8,20,14,50,39,30^{\circ} / \mathrm{d}$, which means that the concomitant tropical year would be closer to $3651 / 4-1 / 117.3$ days than to $3651 / 4-1 / 112$ days. This, of course, is well in line with Bate's own words in the preface to the Book of the World, where he is careful to state that his own estimate comes 'close to the mean between al-Battānī and Ibn Ezra' rather than being exactly at the middle.

Next, it is worth pointing out that a tropical year of $3651 / 4-1 / 112$ days is attested in Latin sources other than the Tabule Machlinenses, albeit none of them earlier than the tables themselves. It features, for instance, in the canons to the so-called Patefit, a tabular work composed between 1329 and 1332 by the astronomer Jean des Murs. According to Jean, 'alBattānī, Ptolemy's successor, says that the quarter-day [that is added to 365 days] is 
diminished by about the $112^{\text {th }}$ part of a day'. ${ }^{73}$ He repeated this claim in a later work, the Epistola super reformatione antiqui kalendari written in 1345 in collaboration with Firmin de Beauval, but this time added a little comparative table of different estimates for the length of the tropical year, which puts the name Albatheny next to an entry for $365 \mathrm{~d} 5 ; 47,9 \mathrm{~h}(=3651 / 4$ - 1/112.0622...d). ${ }^{74}$ The reasons for associating this value with al-Battānī remain opaque, although it may be tempting to conjecture that the bate in Albate(g)ni somehow leads back to the author of the Tables of Mechelen, whose name got corrupted in the chain of transmission.

The other known fourteenth-century astronomer to mention a solar year of $3651 / 4-$ 1/112 days is Heinrich Selder, who in his Tractatus de tempore dominice annunciationis, nativitate et passionis, a work completed no earlier than 1378, claims that the vernal equinox slips through the Julian calendar at a rate of one day every 112 years, 'according to the more truthful observations'. ${ }^{75}$ What these observations were, Selder does not say, but his familiarity with the Tables of Mechelen is clear from his repeated references to them in the Tractatus and in the canons to the Alfonsine Tables he wrote in $1365 .^{76}$ In addition, one

\footnotetext{
${ }^{73}$ MS London, British Library, Royal 12.C.XVII, fol. 205vb: ‘Albategni Ptholomei successor dicit quartam diei minui ex $112^{\text {a }}$ parte diei fere'. The date of the Patefit is discussed in C. Philipp E. Nothaft, 'John of Murs and the Treatise Autores kalendarii (1317): A Problem of Authorship', Sudhoffs Archiv, 99 (2015), 209-229, at pp. $227-228$.

${ }^{74}$ Chris Schabel, 'John of Murs and Firmin of Beauval's Letter and Treatise on Calendar Reform for Clement VI: Text and Introduction', Cahiers de l'Institut du Moyen-Âge Grec et Latin, 66 (1996), 187-215, at p. 197. ${ }^{75}$ MS Munich, Bayerische Staatsbibliothek, Clm 18298, fol. 31rb: 'Sit autem secundum veriores observationes huiusmodi mutatio in 112 annis fere per unum diem, ita ut quartus annus bisextilem diem intercalet'. For Selder's authorship of this text, see Nothaft, 'Vanitas vanitatum' (n. 33), pp. 272-279.

${ }^{76}$ MS Munich, Bayerische Staatsbibliothek, Clm 18298, fols. 27ra, 31rb. For Selder's Canones, see MS Erfurt, Universitäts- und Forschungsbibliothek, Bibliotheca Amploniana, fol. 37, fols. 63v-85v, at fols. 63va, 69va.
} 
should probably mention the curious case of a late-thirteenth-century northern French copy of the canons to the Toledan Tables, to which a contemporary hand added a marginal note listing different estimates of the length of the solar year. One of these is ascribed to a magister Alardus, whose year length of 365d 5;47,15h happens to be in the vicinity of Bate's c.365d 5;47,9h. ${ }^{77}$ The name magister Alardus reappears on a small parchment leaf inserted into a fourteenth-century astronomical codex, which preserves this master's table of stellar coordinates verified in AD 1307 'near Diest in Brabant' (apud Dieste in Brabancia). Other astronomical data recorded on the same leaf concern the time of the vernal equinox of $\mathrm{AD}$ 1308 and the length of the solar year, which is here given as $365 \mathrm{~d} 5 ; 47 \mathrm{~h}^{78}$

Another round value of this sort is reported in Version B of the Tables of Mechelen, which is the only one to come with tables for the annual excess of revolution (revolutio annorum). Contrary to what one may expect, the excess beyond 365 days is here given not as $5 ; 47,9 \mathrm{~h}$, but as 5;47,30h, which would imply a tropical year of $3651 / 4-1 / 115.2$ days. The accompanying text notes that this value is one of several in circulation, but affirms that "this table is believed to be correct and assumes that the length of the solar year always stays the same' ${ }^{79}$ A potential source for the year length used in this table is De iudiciis astrorum, the

\footnotetext{
${ }^{77}$ MS Berlin, Staatsbibliothek, lat. fol. 610, fol. 130r.

${ }^{78}$ MS Erfurt, Universitäts- und Forschungsbibliothek, Bibliotheca Amploniana, qu. 371, Einlegezettel 7. This document was already mentioned by Ernst Zinner, 'Magister Alard von Diest und die Pariser Beobachtungen von 1312-15', Isis, 42 (1951), 38-40 (40). Magister Alardus appears to be the physician Alard of Diest mentioned by Fernand Vercauteren, 'Les médecins dans les principautés de la Belgique et du nord de la France, du VIII' au XIII' ${ }^{\mathrm{e}}$ siècle', Le Moyen Âge, 57 (1951), 61-92 (87, 90).

${ }^{79}$ MS Paris, Bibliothèque nationale de France, n.a.1. 3091, fol. 80v: 'Et nota quod secundum diversitatem ponentium quantitatem anni solaris diversam ibi erit diversitas et inequalitas in revolutionibus et ista tabula
} 
voluminous astrological handbook by 'Alī Ibn Abī l-Rijāl, who was known in Latin as Haly Abenragel. Chapter 15 of Book VI of this work describes some tables relevant to the calculation of anniversary horoscopes, which in the Arabic manuscripts show a year length of 365d 5;47,30h. ${ }^{80}$ Bate cites Haly Abenragel in Part XIX of his Speculum divinorum, thereby indicating that he had seen the Latin translation of De iudiciis astrorum (made in 1254 or shortly thereafter by Aegidius de Tebaldis and Petrus de Regio) by the beginning of the fourteenth century. ${ }^{81}$ This does not necessarily mean, however, that he could derive from it a year length of $365 \mathrm{~d} 5 ; 47,30 \mathrm{~h}$, considering that the table containing this value is absent from the thirteenth-century copy of De iudiciis astrorum annotated by Bate's contemporary Peter of Limoges. ${ }^{82}$ When this table appears in early modern printed editions, the length of the year is always curtailed to $365 \mathrm{~d} 5 ; 47 \mathrm{~h}$, the value endorsed by the aforementioned magister

creditur esse correcta et supposito quantitatem anni solaris esse equale semper et continet 365 dies et 5 horas et 47 minuta et 30 secunda et in istis 5 horis et 47 minutis oriuntur 86 gradus et 52 minuta et 30 secunda'.

${ }^{80}$ Bernard R. Goldstein and José Chabás, 'Planetary Velocities and the Astrological Month', Journal for the History of Astronomy, 44 (2013), 465-478 (468, 472-473).

${ }^{81}$ Bate, Speculum XIX.10, MS Saint-Omer, Bibliothèque municipale, 587, fol. 320v. I owe this reference to David Juste. On the Latin translation of De iudiciis astrorum, see Francis J. Carmody, Arabic Astronomical and Astrological Sciences in Latin Translation: A Critical Bibliography (Berkeley: University of California Press, 1956), pp. 150-152; Gerold Hilty, ed., Aly Aben Ragel: El libro conpildo en los iudizios de las estrellas (Madrid: Real Academia Española, 1956), lxi-lxv; David Juste, 'The Impact of Arabic Sources on European Astrology: Some Facts and Numbers', Micrologus, 24 (2016), 173-194 (186); Dag Nikolaus Hasse, Success and Suppression: Arabic Sciences and Philosophy in the Renaissance (Cambridge, Mass.: Harvard University Press, 2016), pp. 371-372.

${ }^{82}$ MS Paris, Bibliothèque nationale de France, lat. 16206, fol. 174r-v. See Juste, Les manuscrits (n. 38), pp. $234-235$. 
Alardus. ${ }^{83}$ More important, however, is the fact that Bate probably came into contact with De iudiciis astrorum only after writing his Nativitas, ${ }^{84}$ by which time the Tables of Mechelen had already been cast.

Another possibility that has to be taken into account is that Henry Bate may have tried to calculate the length of the tropical year based on the rate of precession and some canonical value for the Sun's rate of sidereal motion. According to the Toledan Tables, the latter was $0 ; 59,8,11,28,27^{\circ} / \mathrm{d}$, making for a sidereal year of approximately $365 ; 15,23,29 \mathrm{~d} .{ }^{85}$ Now, one of the precession values occasionally attested in twelfth- and thirteenth-century manuscripts is an annual rate of $0 ; 0,54^{\circ}$, or $1^{\circ}$ every $66 ; 40$ years. ${ }^{86}$ If this value is combined with the Toledan sidereal mean motion, the resulting tropical year is $360 \div\left(0 ; 59,8,11,28,27^{\circ} / \mathrm{d}+\right.$ $\left.0 ; 0,54^{\circ} \div 365 ; 15 \mathrm{~d}\right) \approx 3651 / 4-1 / 115$ days. An even better fit with Bate's value can be achieved if one uses a round precession value of $1^{\circ}$ every 66 years, which would yield $360 \div$ $\left(0 ; 59,8,11,28,27^{\circ} / \mathrm{d}+1^{\circ} \div 66 \times 365 ; 15 \mathrm{~d}\right) \approx 3651 / 4-1 / 113 \mathrm{~d}$. It has already been seen, however, that the only precession parameter Bate endorses in his works is one of $1^{\circ}$ every 70 years, which would have led him somewhere near a tropical year of $360 \div$ $\left(0 ; 59,8,11,28,27^{\circ} / \mathrm{d}+1^{\circ} \div 70 \times 365 ; 15 \mathrm{~d}\right) \approx 3651 / 4-1 / 125.5$ days.

On balance, there do not seem to be strong reasons to believe that Bate's tropical year of approximately $3651 / 4-1 / 112$ days was the result of pure calculation or merely derived

\footnotetext{
${ }^{83}$ See, e.g., Praeclarissimus in Iudiciis astrorum Albohazen Haly filius Abenragel ([Venice]: Sessa, 1503), fol. 70r. A table showing the unabbreviated value of 365d 5;47,30h appears twice in MS London, Royal Astronomical Society, Add. 1, Vol. 2, fols. 56v, 64r (England, s. XIV ${ }^{\text {med }}$ ). See Pedersen, The Toledan Tables (n. 13), IV, pp. 1586-1587.

${ }^{84}$ As is pointed out in Juste, 'Bate's Nativitas' (n. 51).

${ }^{85}$ Chabás and Goldstein, A Survey (n. 13), p. 57.

${ }^{86}$ Nothaft, 'Criticism of Trepidation Models' (n. 24), p. 222.
} 
from an earlier source. Instead, there is every reason to take seriously his own testimony in the preface to Ibn Ezra's Book of the World, where Bate tells us that he made an effort to compare observations carried out by past astronomers (Ptolemy and al-Battān̄i) as well as by himself. The instruction manual for this sort of project had been provided by Ibn Ezra, who in the same Book of the World illustrates the basic steps necessary to determine the length of the tropical year from the times of vernal equinoxes separated by a large span of years. To find the time of the vernal equinox in a given year, it is expedient first to measure the Sun's noon altitude on the appropriate day and then to compare the result with the co-latitude of the place where the measurement takes place. The latter value can be obtained by measuring the Sun's noon altitude at the solstices and taking the middle between these two extremes. At the time of the equinox, the Sun's declination changes very swiftly, by about $0 ; 24^{\circ}$ per day, which means that it is licit simply to take the difference between the co-latitude and the equinoctial noon altitude, and then add or subtract one hour for each minute of arc in order to get from noon to the actual hour of the equinox. ${ }^{87}$

What makes these instructions especially noteworthy is the fact that we have evidence they were followed by astronomers in Bate's own environment. One case in point is the aforementioned Peter of Limoges, whom Bate is likely to have interacted with in some form or another. ${ }^{88}$ A valuable record of Peter's observational activities comes from a note he entered into a book he owned. ${ }^{89}$ Some of its contents are very reminiscent of a passage in

\footnotetext{
${ }^{87}$ Abraham Ibn Ezra, Book of the World, first version, §14-16, ed. and trans. Sela (n. 67), pp. 60-63.

${ }^{88}$ Peter of Limoges's astronomical-astrological activities and potential contacts with Henry Bate are discussed in Juste, 'Bate's Nativitas' (n. 51).

${ }^{89}$ MS Vatican, Biblioteca Apostolica Vaticana, Reg. lat. 1191, fol. 139r. This note was transcribed by Ferdinand M. Delorme, 'Manuscrit du “Computus” de Roger Bacon annoté par Guillaume de Saint-Cloud', Antonianum,
} 
Bate's Speculum divinorum, which mentions that in recent times two astronomers based in Paris had built very large quadrants to measure the Sun's noon altitude at the summer solstice. When they took this measurement independently from each other, they arrived at different results of respectively $64 ; 42^{\circ}$ and $64 ; 45^{\circ} .{ }^{90}$ This may well be a reference to the work carried out by Peter of Limoges and a certain Franco, who is presumably to be identified with the astronomer Franco of Poland. ${ }^{91}$ According to Peter's note, Franco had made observations in 1281 that showed the Sun's altitude at the two solstices to be $64 ; 43^{\circ}$ and $17 ; 37^{\circ}$. In 1283 , the two joined forces to repeat the measurement for the winter solstice, for which purpose they used a large quadrant with a gradation of 5 minutes of arc. The result was $17 ; 35^{\circ}$, two minutes below Franco's first measurement. If compared with the value previously obtained for the summer solstice, this gave $\left(64 ; 43^{\circ}-17 ; 35^{\circ}\right) \div 2=23 ; 34^{\circ}$ for the obliquity of the ecliptic and $17 ; 35^{\circ}+23 ; 34^{\circ}=41 ; 9^{\circ}$ for the co-latitude, which is rounded to $41 ; 10^{\circ}$ in the text. ${ }^{92}$ Seven years later, in 1290, Peter joined the astronomer William of Saint-Cloud in

11 (1936), 554-562 (559). Further references are provided in Nothaft, 'Criticism of Trepidation Models' (n. 24), pp. 219-220.

${ }^{90}$ Bate, Speculum XXII.17, ed. Steel and Guldentops (n. 3), p. 337: 'Nostro quoque tempore Parisius artificiosi viri duo simul, duobus maximis quadrantibus artificiose factis et ingeniose verificatis, elevationem solis maximam in meridie solstitii scilicet aestivalis acceperunt, quam alter quidem illorum invenit esse 64 gradus [recte graduum] 42 minutorum, alter vero 64 gradus [recte graduum] 45 minutorum, eratque sic illorum differentia 3 minutorum'.

${ }^{91}$ See $n .108$ below.

${ }^{92}$ MS Vatican, Biblioteca Apostolica Vaticana, Reg. lat. 1191, fol. 139r. Compare the similar account in William of Saint-Cloud, Almanach planetarum (§2-4), ed. Fritz S. Pedersen, 'William of Saint-Cloud: Almanach Planetarum; An Edition of the Canons, A Few Samples from the Tables, and a Foray into the Numbers', Cahiers de l'Institut du Moyen-Âge Grec et Latin, 83 (2014), 1-133 (8-9). William says he derived the co-latitude of $41 ; 10^{\circ}$ from solstitial noon altitudes $17 ; 36^{\circ}$ and $64 ; 44^{\circ}$. An earlier set of results for these 
using this value to determine the approximate time of the vernal equinox. A measurement of the noon shadow on 11 March that year showed the Sun to be at an altitude of $40 ; 30^{\circ}$. There was hence still a gap of $41 ; 10^{\circ}-40 ; 30^{\circ}=0 ; 40^{\circ}$ relative to the local co-latitude, which indicated that the Sun had another 40 hours to go until crossing the equator (on 13 March at 4 a.m.). ${ }^{93}$

It is not difficult to see how the method prescribed by Ibn Ezra and employed by Peter of Limoges and William of Saint-Cloud in 1290 could have assisted Henry Bate in determining a new value for the length of the tropical year. All he had to do was to compare the observed time of an equinox in the present with a reliably recorded equinox of the distant past. One fairly obvious candidate for the latter would have been the vernal equinox of AD 140, which according to Ptolemy's Almagest (III.1) occurred on 22 March at 1 p.m. ${ }^{94}$ That Bate paid special attention to the data in the Almagest when creating his Tables of Mechelen is suggested inter alia by the fact that all of the collected-year tables put their initial value, or

parameters is recorded in a marginal note in MS London, British Library, Harley 4350, fol. 119v (Paris/Northern France, s. XIII ${ }^{3 / 4}$ ), where the co-latitude of Paris is given as $41 ; 12^{\circ}$ and the noon altitude at the winter solstice as $17 ; 38 ; 47^{\circ}$ (which implies an obliquity of $23 ; 33,13^{\circ}$ ). See also MS London, British Library, Harley 3735 , fol. 73 ra (s. XIII ${ }^{\text {ex }}$ [c.1293]), which gives the obliquity as $23 ; 34^{\circ}$, the co-latitude of Paris as $41 ; 12^{\circ}$, and the noon altitude at the summer solstice as $64 ; 46^{\circ}$.

${ }^{93}$ MS Vatican, Biblioteca Apostolica Vaticana, Reg. lat. 1191, fol. 139r. William of Saint-Cloud's involvement is revealed by the parallel transmission of the same note in MS Vienna, Österreichische Nationalbibliothek, 2311, fol. 96v, which mentions Peter in the third person and specifies the place where the observation took place as Saint-Cloud, and by William's own account in his Almanach planetarum of 1292. See Pedersen, 'William of Saint-Cloud' (n. 92), pp. 9-10 (§5).

${ }^{94}$ See Ptolemy, Almagest, trans. G. J. Toomer, 2nd ed. (Princeton, NJ: Princeton University Press, $1998\left[1^{\text {st }}\right.$ edn 1984]), p. 138. Ptolemy's result was off by nearly a day, as the actual vernal equinox in AD 140 occurred on 21 March, between 4 and 5 p.m. 
radix, at 120 completed years of the Christian era, which means that the first 20 years covered by Bate's tables (AD 121-140) coincide roughly with the period during which Ptolemy carried out his observations. ${ }^{95}$ Another important hint comes from the headings in Version A, which give the time difference between Mechelen and Alexandria Ptholomei as $1 ; 30 \mathrm{~h}$, which is the equivalent of $22 ; 30^{\circ}$ in longitude. This information would have been crucial for any comparison between a newly observed planetary position and any of those observed by Ptolemy, which obviously had to be corrected for differences in geographic longitude. In the case of Ptolemy's equinox on 22 March AD 140, Bate would have had to decrease its time from 1 p.m. to 11.30 a.m.

Since Bate himself has left us no recorded observations of the equinox at Mechelen, we may instead compare Ptolemy's equinox with that observed by Bate's colleagues in AD 1290 (13 March, 4 a.m.), which is within two hours of the result achieved by modern calculation (13 March, 05:49:14 GMT). ${ }^{96}$ Taking into account the longitude difference just mentioned, the distance in time between these two equinoxes would amount to $420,027 \mathrm{~d}$ 16;30h. Over the 1150 tropical years that separate them, this makes for an average year length of $365 \mathrm{~d} 5 ; 47,42,46,57 \ldots \mathrm{h} \approx 3651 / 4-1 / 117.2 \mathrm{~d}$. This comes appreciably close to the year length Henry Bate used for his Tabule Machlinenses, being almost exactly at the aforementioned middle between the values of al-Battānī and Ibn Ezra.

\footnotetext{
${ }^{95}$ See the list in Pedersen, A Survey (n. 64), pp. 416-422.

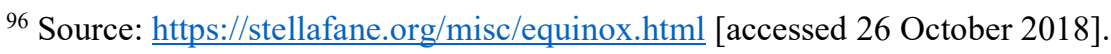




\section{Mean motion parameters in the Tabule Machlinenses}

Apart from the lunar node, where the Tables of Mechelen appear to follow Ibn Ezra's Tables of Pisa,${ }^{97}$ the only instances where the entries in Versions A and B converge on the same mean motion parameter are the mean motion of the Sun and the mean motions in anomaly of the Moon and Mercury. In all other cases, the two recensions differ to a considerable degree. For the sake of brevity, I shall summarize the data yielded by their respective mean motion tables in Table 3.

\section{$<$ Table 3 here $>$}

From the added comparisons with the values implicit in the Tables of Pisa, it can readily be seen that Bate generally increased, but in a few cases significantly decreased the mean motion rates that had been presupposed by his main model. Such decrease is particularly noticeable for Mercury, which in both versions of Bate's tables shows a tabulated surplus of $14 ; 26,11^{\circ}$ after 20 Julian years. This value happens to be compatible with the daily mean motion of $3 ; 6,24,6,59,35,50^{\circ}$ Ptolemy derived in the ninth book of his Almagest (IX.3). ${ }^{98}$ If it is multiplied by the 7305 days contained in 20 Julian years, the value yields 63 full revolutions with a surplus of $14 ; 26,11,25 \ldots{ }^{\circ}$ The same sort of conclusion can be drawn for Bate's treatment of the Moon, which according to the Almagest (IV.3) has a daily mean motion in anomaly of $13 ; 3,53,56,17,51,59^{\circ}$. Over 20 Julian years or 7305 days, this value yields 265 full revolutions with a surplus of $39 ; 41,59,15 \ldots{ }^{\circ}$, in splendid agreement with what we find in both extant versions of the Tables of Mechelen.

\footnotetext{
${ }^{97}$ As was pointed out by Pedersen, 'The Astronomical Tables' (n. 23), p. 9, the preserved copies of the Tables of Pisa are ambiguous as to whether the tables for the lunar node were intended to be based on a 20-year increment of $26 ; 49,17^{\circ}$ or 26;47,17․ In line with Mercier, 'The Lost Zijj' (n. 23), pp. 3, 24, I accept the former value and hence assume that Bate took this mean motion parameter from Ibn Ezra.

${ }^{98}$ Ptolemy, Almagest, trans. Toomer (n. 94), p. 425.
} 
Other than copying mean motion parameters wholesale, another way in which Bate could have mined the Almagest for data was to use the period relations Ptolemy established between the Sun and the other planets and adjust the resulting mean motions for a different length of the tropical year. A blueprint for this sort of activity was provided by Almagest IV.3, where Ptolemy shows how to obtain the Moon's daily mean motion in longitude, $m$, from the relation $m=\left(s \cdot \eta+360^{\circ}\right) / \eta$, where $s$ is the daily mean motion of the Sun and $\eta$ is the length of the mean synodic month. ${ }^{99}$ If Bate accepted Ptolemy's value for $\eta$ $(29 ; 31,50,8,20 \mathrm{~d})$, his table for the mean Sun, which is the same in Versions A and B, would given him the following output:

$\frac{\left.7200 ; 10,33,19^{\circ} \div 7305 d \cdot 29 ; 31,50,8,20 d+360^{\circ}\right)}{29 ; 31,50,8,20 d}=13 ; 10,35,1,49,2,19 / \mathrm{d}^{\circ}$.

This is so close to the value implicit in Version B $\left(13 ; 10,35,1,49,2,35^{\circ}\right)$ as to make it practically certain that Bate, like previous Islamic astronomers, made an effort to maintain the Ptolemaic length of the mean synodic month, which also underpinned the syzygy tables of al-Battānī and the Jewish calendar. ${ }^{100}$

Having thus accounted for the mean motion rates (but not the radices) Bate used when calculating the tables for the Moon and Mercury, it may seem that, contrary to his own claims, the Tables of Mechelen were just another medieval Latin work that was largely derivative of the results achieved by earlier Greek and Islamic astronomers. Yet the remaining planets fail to fit this pattern, as none of the mean motion parameters assumed for them in Versions A and B seem to be traceable back to an earlier source. ${ }^{101}$ Nor does it seem

\footnotetext{
${ }^{99}$ Ptolemy, Almagest, trans. Toomer (n. 94), p. 179.

${ }^{100}$ See on this parameter Bernard R. Goldstein, 'Ancient and Medieval Values for the Mean Synodic Month', Journal for the History of Astronomy, 34 (2003), 65-74.

${ }^{101}$ For a list of mean motion parameters known in medieval Europe, see Chabás and Goldstein, A Survey (n. 13), p. 59.
} 
possible to account for them merely on the basis of Bate's unusual value for the tropical year, which he might have used as a yardstick to scale up the mean motions of the remaining planets. Let us take as a quick example the mean motion in anomaly of Saturn, which Ptolemy, in Almagest IX.3, derives from the assumption that the planet makes 57 revolutions in anomaly in 59 solar years $+1 ; 45$ days. On a solar year of $365 ; 14,48 d$, this yields an anomalistic mean motion of $20520^{\circ} \div 21551 ; 18 \mathrm{~d}=0 ; 57,7,43,41,43,39,41 \ldots \%$ d, which Ptolemy ends up rounding to $0 ; 57,7,43,41,43,40^{\circ} / \mathrm{d} .{ }^{102}$ Bate may have been tempted to adjust this value by replacing Ptolemy's solar year with his own, in which case 59 solar years + $1 ; 45 \mathrm{~d}$ would have turned out to be equivalent to $59 \times 365 ; 14,27,52,23 \ldots \mathrm{d}+1 ; 45 \mathrm{~d}=$ $21550 ; 58,24,30,58,48,33 \ldots$.. If he had followed this path, his result for Saturn's mean motion in anomaly would have been $0 ; 57,7, \underline{46}, 48 \ldots \%$ d. For the mean motion in longitude, his solar parameter would have given him $0 ; 59,8,20,28 \ldots \circ / \mathrm{d}-0 ; 57,7,46,48 \ldots \circ / \mathrm{d}=0 ; 2,0, \underline{33}, 40 \ldots \% / \mathrm{d}$. In reality, Bate's tables imply much swifter mean motion values of $0 ; 2,0,36,30 \ldots \%$ d (Version A) and $0 ; 2,0, \underline{37}, 11 \ldots \%$ d (Version B) and, concomitantly, more moderate mean motions in anomaly of $0 ; 59,8,20,28 \ldots \% \mathrm{~d}-0 ; 2,0,36,30 \ldots \% / \mathrm{d}=0 ; 57,7, \underline{43}, 58 \ldots \%$ d $($ Version $\mathrm{A})$ and $0 ; 59,8,20,28 \ldots \% / \mathrm{d}-0 ; 2,0,37,11 \ldots \% \mathrm{~d}=0 ; 57,7, \underline{43}, 17 \ldots \%$ d (Version $\mathrm{B})$.

The case of Venus is similar, as Ptolemy here assumes that $1800^{\circ}$ in anomaly are completed in 8 tropical years $-2 ; 18 \mathrm{~d}$, making him arrive at a mean motion in anomaly of $0 ; 36,59, \underline{25}, 53,11,28^{\circ} / \mathrm{d}$. Using his year length in place of Ptolemy's, Bate could have scaled this up to $0 ; 36,59, \underline{27}, 37 \ldots \%$, which still falls short of the values implicit in his tables: $0 ; 36,59, \underline{30}, 28 \ldots \%$ d (Version A) and 0;36,59, $\underline{29}, 32 \ldots \%$ d (Version B). Both here and in the case of Saturn, Version B decreases the value of the mean motion in anomaly relative to Version A, but this is not true across the board, as the corresponding motion of Jupiter is greater in

\footnotetext{
102 Ptolemy, Almagest, trans. Toomer (n. 94), p. 424.
} 
Version B than it is in Version A. Further details may be gleaned from Table 4 below, which compares the anomalistic mean motions of the three superior planets implicit in the Tabule Machlinenses with those Bate would have been able to find in the Almagest or infer from alBattānī, the Tables of Pisa, and the ubiquitous Toledan Tables.

$<$ Table 4 here $>$

The results are striking in that the parameters for these planets vary independently from each other. This holds true both for the comparison between the two extant recensions of Bate's own tables and for the comparison between either version and the sources just mentioned. Under these circumstances, one can safely exclude that the divergent planetary parameters encountered in the Tables of Mechelen were simply a by-product of Bate's adoption of a different solar year. ${ }^{103}$ A different mechanism must have been at work. Given Bate's own testimony, observations of planetary longitudes are very likely to have been part of it.

\section{Concluding remarks}

Since the two extant versions of Henry Bate's Tables of Mechelen come without any detailed remarks about their construction, it is difficult to draw firm conclusions about the operational steps the Flemish astronomer may have followed in establishing the mean motion parameters that set his tables apart from others constructed or used in the late thirteenth century. That observations played a significant role in the overall process is very strongly suggested by

\footnotetext{
103 This also holds true in the sense that Bate did not simply use the ratio between his tropical year length and that assumed in his source to adjust an existing set of planetary mean motions. For a fifteenth-century example of this modus operandi, see C. Philipp E. Nothaft, 'John Holbroke, the Tables of Cambridge, and the "True Length of the Year": A Forgotten Episode in Fifteenth-Century Astronomy', Archive for History of Exact Sciences, 72 (2018), 63-88 (68-75).
} 
Bate himself, who in his annotations to Version B claims to have used observationes instrumentorum as a means by which to correct a previous version. ${ }^{104} \mathrm{He}$ reveals a bit more about his modus operandi in the postscript to Part XXII of the Speculum divinorum and in his astrological autobiography (Nativitas), where he alludes to having compared Ptolemy's ancient observations with his own. ${ }^{105}$ In addition, we have the preface to his translation of Ibn Ezra's Book of the World, where Bate tells us upfront that he proposed a value for the Sun's mean motion that conformed to observations carried out by Ptolemy and al-Battānī as well as by himself. ${ }^{106}$

These claims are all credible in light of the results presented above. In particular, we have seen that Bate founded his tables on a value for the tropical year that is not attested in the earlier literature, but which may have plausibly been derived by comparing the time of an observed vernal equinox with earlier such data. For the motions of the Moon, he had good reason to follow the excellent values for the synodic month and period of anomaly that had been transmitted as part of the Almagest. He also took recourse to Ptolemy's data when drawing up tables for Mercury, which was by far the most difficult planet to observe, but went his own way when dealing with the other four wandering stars. The mean motion rates for Saturn, Jupiter, Mars, and Venus in the Tables of Mechelen are not related in any obvious way to those in the Tables of Pisa or other potential sources. Indeed, a look at the extent and nature of their variance from known parameters strongly suggests that Bate derived them independently from each other, which is at the very least consistent with the idea that he based himself on empirical data.

\footnotetext{
${ }^{104}$ See n. 47 above.

${ }^{105}$ See nn. 12 and 37 above.

${ }^{106}$ See n. 72 above.
} 
If the findings presented thus far are correct, it follows that the Tables of Mechelen were highly unusual among the medieval astronomical tables drawn up north of the Pyrenees in that they featured an original set of parameters for planetary mean motions. Since the mean motions of the planets are one of the key hallmarks used in distinguishing astronomical tables from each other, it seems justified to classify Bate's tables as the earliest known set of tables produced by a Latin astronomer in the Middle Ages. In order to elucidate their background a bit further, it may be worth confronting them with the available evidence for the practice of astronomy in late-thirteenth-century Paris, some of which points to a heightened interest in planetary observations. An early source in this regard is Bate's own description of a modified version of the astrolabe (Magistralis compositio astrolabii), written in 1274, in which he envisioned a two-step process of establishing planetary coordinates. The first was to use a type of quadrant to determine the horizontal altitude and position relative to the meridian, while the second was to convert this information into ecliptic longitude and latitude by using the horizon plate of his astrolabe. ${ }^{107}$ A method that bypassed the first part of this cumbersome procedure was soon offered to Bate's contemporaries by a sophisticated new instrument, the turquet (turketus), which made it possible to locate celestial objects in the ecliptic plane of reference directly. The earliest datable description of the turquet was completed on 2 July 1284 by Franco of Poland, who is probably identical with the Franco who carried out solar

\footnotetext{
${ }^{107}$ Henry Bate, Magistralis compositio astrolabii, ed. Gunther, The Astrolabes (n. 43), 2:372. On Bate’s astrolabe see Emmanuel Poulle, 'L'astrolabe médiéval d'après les manuscrits de la Bibliothèque nationale', Bibliothèque de l'École des chartes, 112 (1954), 81-103 (93-94); Poulle, 'Les instruments astronomiques de l'Occident latin aux XI' et XII' siècles', Cahiers de civilisation médiévale 15 (1972): 27-40 (40); Poulle, 'Henry Bate of Malines', Complete Dictionary of Scientific Biography, 27 vols. (Detroit: Charles Scribner's Sons, 2008), VI, pp. 272-275 (273).
} 
observations in Paris in 1281 and 1283 (in collaboration with Peter of Limoges). ${ }^{108}$ Although costly and difficult to construct and set up, the turquet would have been a very useful companion for any astronomer who, like Henry Bate, was interested in revising existing parameters on an empirical basis. This impression is strengthened by the final chapter of Franco of Poland's Tractatus de turketo, in which he briefly explained how the instrument can be used to determine ecliptical longitudes and latitudes of both the fixed and wandering stars and, by consequence, to gauge the extent to which the 'Toledan Tables, or those for other cities, stray from their true places'. How these tables might actually be rendered more adequate was not a topic Franco discussed in any depth. He instead promised his readers that he would expound it elsewhere, 'God willing'. 109

A relatively simple approach to correcting tables was pursued around the same time by the aforementioned William of Saint-Cloud, who used conjunctions of Jupiter and Saturn

\footnotetext{
${ }^{108}$ Aleksander Birkenmajer, 'Les astronomes et les astrologues silésiens au Moyen Âge’ [1937], in idem, Études d'histoire des sciences en Pologne (Wrocław: Zakład Narodowy im. Ossolińskich, 1972), pp. 437-468 (444448); Lynn Thorndike, 'Franco de Polonia and the Turquet', Isis, 36 (1945), 6-7; Ernst Zinner, Deutsche und niederländische astronomische Instrumente des 11.-18. Jahrhunderts (Munich: Beck, 1956), pp. 177-183; Emmanuel Poulle, 'Bernard de Verdun et le turquet', Isis, 55 (1964), 200-208; Giles M. Hudson, 'Torquetum', in Instruments of Science: An Historical Encyclopedia, ed. Robert Bud and Deborah Jean Warner (New York/London: Garland, 1998), pp. 623-626.

${ }^{109}$ See the earliest known copy of the Tractatus de turketo in MS Paris, Bibliothèque nationale de France, lat. 7333, fols. 49ra-52va (s. XIII/XIV), at fol. 52rb: 'Eodem modo facies de aliis stellis fixis et similiter de planetis et scies certissime in quanto er $<\mathrm{r}>$ ant tabule Toletale $[$ sic $]$ vel aliarum civitatum a veris locis ipsarum et hoc adverte. Modum autem verificationis tabularum predictarum alias exponam nutu Dei'. A transcription of the whole text, as found in MS Oxford, Bodleian Library, Ashmole 1522, fols. 176r-178v (s. XIV ${ }^{1 / 2}$ ), appears in Robert T. Gunther, Early Science in Oxford, vol. 2, Astronomy (Oxford: Oxford University Press, 1923), pp. $370-375$.
} 
and the stations and retrogradations of Mars to detect predictive errors made by the Toledan Tables and one of their principal Christian offshoots, the Tables of Toulouse. His Almanach planetarum, which covered the 20 years from 1292 to $1311,{ }^{110}$ was meant to minimize these errors, although it seems that William preferred ad hoc adjustments to the epoch values to actual revisions of the underlying parameters. In spite of this limitation, the preface to his Almanach is an invaluable source for offering us the kind of information Bate's tables are silent on, by giving at least some indication of how William used observational data in his computations. ${ }^{111} \mathrm{He}$ took the glaring errors produced by the standard tables as a sign that 'it has been a long time since any observations were made by means of instruments in order to correct the places of the planets or even of the fixed stars', ${ }^{112}$ which may reflect a lack of awareness of Henry Bate's Tables of Mechelen or, rather, of the observations that had gone into their construction. One point on which William and Henry clearly agreed was their preference for an astronomy based on the ninth sphere, which looked more and more attractive the more the precession-as-trepidation model inherent in the Toledan Tables

\footnotetext{
${ }^{110}$ The tables of this Almanach survive in two manuscripts, both of them written close to the time of original composition. See MSS Paris, Bibliothèque nationale France, lat. 16210, fols. 2r-229v (commissioned by Peter of Limoges), and Vatican, Biblioteca Apostolica Vaticana, lat. 4572, fols. 1r-102v.

${ }^{111}$ See the edition and translation of the whole preface in Pedersen, 'William of Saint-Cloud' (n. 92), pp. 8-56, as well as Richard I. Harper, 'The Kalendarium Regine of Guillaume de St.-Cloud' (PhD Diss., Emory University, 1966), pp. 41-56; José Luis Mancha, 'Astronomical Use of Pinhole Images in William of SaintCloud's Almanach Planetarum (1292)', Archive for History of Exact Sciences, 43 (1992), 275-298; Stephen C. McCluskey, Astronomies and Cultures in Early Medieval Europe (Cambridge: Cambridge University Press, 1998), pp. 205-206.

112 William of Saint-Cloud, Almanach planetarum (§25), trans. Pedersen, 'William of Saint-Cloud’ (n. 92), p. 47.
} 
struggled to predict the correct gap between the two reference frames, tropical and sidereal. ${ }^{113}$ When William compared the observed time of the vernal equinox in 1290 to the sidereal longitudes produced by the Tables of Toulouse, he found a difference of $10 ; 13^{\circ}$, even though the common model allowed for no more than $9 ; 23^{\circ} .{ }^{114}$ By 1292 , the starting year of William's Almanach, the difference had increased to $10 ; 15^{\circ}$, which happens to be identical to the value a marginal note in a contemporary astronomical manuscript ascribes to a certain Henry of Mechelen. ${ }^{115}$

Nothing more is known about the rationale behind this value, whose original source has probably disappeared. It is just one of many reminders of the tremendous gaps that exist in our record of what Henry Bate and other medieval astronomers did or hoped to accomplish when they observed the stars at night. The survival of two recensions of his Tables of Mechelen is particularly fortunate in this respect, as it allows us to read between the lines and catch a glimpse of the lost richness of late-thirteenth-century Latin astronomy, whose intellectual acumen and observational focus appear to have been a good deal greater than often suspected.

\footnotetext{
${ }^{113}$ Nothaft, 'Criticism of Trepidation Models' (n. 24), pp. 213-227, 235.

${ }^{114}$ William of Saint-Cloud, Almanach planetarum (§2-6), ed. Pedersen, 'William of Saint-Cloud' (n. 92), pp. 810.

${ }^{115}$ MS London, British Library, Royal 12.C.IX, fol. 29v (s. XIII/XIV): 'Henricus de Machilinio ponit pro motu octave spere 10 gradus et 15 minuta'. See Pedersen, The Toledan Tables (n. 13), I, p. 129.
} 


\begin{tabular}{|c|c|c|c|}
\hline & NC 282 & Mechelen A & Mechelen B \\
\hline Sun & $9 \mathrm{~s} 29 ; 3,55^{\circ}$ & $9 \mathrm{~s} 29 ; 3,55^{\circ}$ & $9 \mathrm{~s} 29 ; 3,55^{\circ}$ \\
\hline Moon (long.) & $7 \mathrm{~s} 12 ; 45,6^{\circ}$ & $7 \mathrm{~s} 12 ; 46,50^{\circ}$ & $7 \mathrm{~s} 12 ; 45,26^{\circ}$ \\
\hline Moon (anom.) & $3 \mathrm{~s} 11 ; 26,53^{\circ}$ & $3 \mathrm{~s} 4 ; 26,53^{\circ}$ & $3 \mathrm{~s} 4 ; 54,2^{\circ}$ \\
\hline Saturn & $8 \mathrm{~s} 28 ; 50,10^{\circ}$ & $8 \mathrm{~s} 28 ; 50,10^{\circ}$ & $8 \mathrm{~s} 29 ; 59,36^{\circ}$ \\
\hline Jupiter & $8 \mathrm{~s} 28 ; 52,55^{\circ}$ & $8 \mathrm{~s} 28 ; 52,55^{\circ}$ & $8 \mathrm{~s} 28 ; 41,48^{\circ}$ \\
\hline Mars & $11 \mathrm{~s} 4 ; 34,34^{\circ}$ & $11 \mathrm{~s} 4 ; 34,34^{\circ}$ & $11 \mathrm{~s} 6 ; 21,56^{\circ}$ \\
\hline Venus (anom.) & $9 \mathrm{~s} 1 ; 59,28^{\circ}$ & $9 \mathrm{~s} 3 ; 25,3^{\circ}$ & $9 \mathrm{~s} 2 ; 1,28^{\circ}$ \\
\hline Mercury (anom.) & $3 \mathrm{~s} 7 ; 43,7^{\circ}$ & $3 \mathrm{~s} 7 ; 32,7^{\circ}$ & $3 \mathrm{~s} 7 ; 32,7^{\circ}$ \\
\hline
\end{tabular}

Table 1: Mean longitudes for 15 January AD 988, as recorded in MS Oxford, New College, 282, fol. $197 \mathrm{r}-\mathrm{v}$, and as calculated using the Tables of Mechelen, Versions A and B. 


\begin{tabular}{|c|c|c|c|c|}
\hline \multicolumn{5}{|c|}{ Medius solis in expansis } \\
\hline Anni & Signa & gradus & minuta & secunda \\
\hline 1 & 11 & 29 & 45 & 44 \\
\hline 2 & 11 & 29 & 31 & 29 \\
\hline 3 & 0 & 0 & 16 & 22 \\
\hline 4 & 0 & 0 & 2 & 6 \\
\hline 5 & 11 & 29 & 47 & 51 \\
\hline 6 & 11 & 29 & 33 & 36 \\
\hline 7 & 0 & 0 & 18 & 29 \\
\hline 8 & 0 & 0 & 4 & 13 \\
\hline 9 & 11 & 29 & 49 & 58 \\
\hline 10 & 11 & 29 & 35 & 42 \\
\hline 11 & 0 & 0 & 20 & 35 \\
\hline 12 & 0 & 0 & 6 & 20 \\
\hline 13 & 11 & 29 & 52 & 4 \\
\hline 14 & 11 & 29 & 37 & 48 \\
\hline 15 & 0 & 0 & 32 & 42 \\
\hline 16 & 0 & 0 & 8 & 27 \\
\hline 17 & 11 & 29 & 54 & 11 \\
\hline 18 & 11 & 29 & 39 & 56 \\
\hline 19 & 0 & 0 & 24 & 49 \\
\hline 20 & 0 & 0 & 10 & 33 \\
\hline
\end{tabular}

Table 2a: The expanded-year table for the mean solar motion in the Tables of Mechelen (MS Paris 3091, fol. 79v). 


\begin{tabular}{|c|c|c|c|c|}
\hline \multicolumn{5}{|c|}{ Medius solis in annis collectis } \\
\hline Anni & Signa & gradus & minuta & secunda \\
\hline 120 & 11 & 6 & 31 & 59 \\
\hline 560 & 11 & 10 & 24 & 12 \\
\hline 980 & 11 & 14 & 5 & 52 \\
\hline 1200 & 11 & 16 & 1 & 58 \\
\hline 1220 & 11 & 16 & 12 & 31 \\
\hline 1240 & 11 & 16 & 23 & 5 \\
\hline 1260 & 11 & 16 & 33 & 38 \\
\hline 1280 & 11 & 16 & 44 & 11 \\
\hline 1300 & 11 & 16 & 54 & 45 \\
\hline 1320 & 11 & 17 & 5 & 18 \\
\hline
\end{tabular}

Table 2b: The collected-year table for the mean solar motion in the Tables of Mechelen (MS Paris 3091, fol. 79v). 


\begin{tabular}{|c|c|c|c|}
\hline \multicolumn{4}{|c|}{ Motions per 20 years (7305 days) ${ }^{116}$} \\
\hline & Mechelen A & Mechelen B & Pisa $^{117}$ \\
\hline Sun & $20 \mathrm{r}+0 ; 10,33,[19]^{\circ}$ & $20 \mathrm{r}+0 ; 10,33,19^{\circ}$ & $20 \mathrm{r}+0 ; 9^{\circ}$ \\
\hline Moon & $267 \mathrm{r}+$ & $267 \mathrm{r}+$ & $267 \mathrm{r}+133 ; 33,34^{\circ} 119$ \\
\hline Moon (arg.) & $265 \mathrm{r}+39 ; 41,59^{\circ}$ & $265 \mathrm{r}+39 ; 41,59^{\circ}$ & {$\left[265 \mathrm{r}+39 ; 46,50^{\circ}\right]^{120}$} \\
\hline Lunar Node & $1 \mathrm{r}+26 ; 49,17^{\circ}$ & $1 \mathrm{r}+26 ; 49,17^{\circ}$ & $1 \mathrm{r}+26 ; 49,17^{\circ}$ \\
\hline Saturn & $0 \mathrm{r}+244 ; 44,4,[4]^{\circ}$ & $0 \mathrm{r}+244 ; 45,28,33,25^{\circ}$ & $0 \mathrm{r}+244 ; 40,2^{\circ}$ \\
\hline Jupiter & $1 \mathrm{r}+247 ; 17,11,[18]^{\circ}$ & $1 \mathrm{r}+247 ; 16,55,[16]^{\circ}$ & $1 \mathrm{r}+247 ; 16,25^{\circ}$ \\
\hline Mars & $10 \mathrm{r}+228 ; 20,14,[53]^{\circ}$ & $10 \mathrm{r}+228 ; 22,44,55^{\circ}$ & $10 \mathrm{r}+228 ; 19,10^{\circ}$ \\
\hline Venus (arg.) & $12 \mathrm{r}+183 ; 45,[5],[47]^{\circ}$ & $12 \mathrm{r}+183 ; 43,11,39,43^{\circ}$ & $12 \mathrm{r}+183 ; 43,18^{\circ}$ \\
\hline Mercury & $63 \mathrm{r}+14 ; 26,11,[26]^{\circ}$ & $63 \mathrm{r}+14 ; 26,11,[26]^{\circ}$ & $63 \mathrm{r}+14 ; 28,50^{\circ}$ \\
\hline (arg.) & & & \\
\hline & & & \\
\hline & & & \\
\hline & & & \\
\hline
\end{tabular}

${ }^{116}$ Square brackets indicate that the sexagesimal in question is implicit in the increase over 1200 years in the table of collected years, but not tabulated in the table of expanded years.

${ }^{117}$ See Pedersen, 'The Astronomical Tables' (n. 23), pp. 7-12, and the summary list in Mercier, 'The Lost Zīj' (n. 23), 24, which I have checked against MSS Paris, Bibliothèque nationale de France, lat. 16207, fols. 20v36r; Paris, Bibliothèque nationale de France, lat. 16208, fol. 4r-v.

${ }^{118}$ This is the value in the final line of the extended-year table. It also appears to have been used for the 20 -year increments in the collected-year table, although parts of this table have been miscalculated or disfigured by scribal error.

${ }^{119}$ I here accept the emendation suggested by Mercier, 'The Lost Zìj' (n. 23), p. 4.

${ }^{120}$ This value is probably corrupt and should be emended to $265 r+39 ; 41,59^{\circ}$. See Mercier, 'The Lost Zīj' (n. 23), p. 24; Pedersen, 'The Astronomical Tables' (n. 23), p. 16n18. 


\begin{tabular}{|c|c|c|c|}
\hline & Mechelen A & Mechelen B & Pisa \\
\hline Sun & $0 ; 59,8,20,28,44,21^{\circ}$ & $0 ; 59,8,20,28,44,21^{\circ}$ & $0 ; 59,8,19,42,45,5^{\circ}$ \\
\hline Moon & $13 ; 10,35,1,49,11,57^{\circ}$ & $13 ; 10,35,1,49,2,35^{\circ}$ & $13 ; 10,35,1,8,30,3^{\circ}$ \\
\hline Moon (arg.) & $13 ; 3,53,56,17,44,28^{\circ}$ & $13 ; 3,53,56,17,44,28^{\circ}$ & {$\left[13 ; 3,53,58,41,8,59^{\circ}\right]$} \\
\hline Lunar Node & $0 ; 3,10,37,50,23,24^{\circ}$ & $0 ; 3,10,37,50,23,24^{\circ}$ & $0 ; 3,10,37,50,23,24^{\circ}$ \\
\hline Saturn & $0 ; 2,0,36,30,5,40^{\circ}$ & $0 ; 2,0,37,11,43,56^{\circ}$ & $0 ; 2,0,34,30,48,2^{\circ}$ \\
\hline Jupiter & $0 ; 4,59,16,43,30,55^{\circ}$ & $0 ; 4,59,16,35,36,50^{\circ}$ & $0 ; 4,59,16,20,41,53^{\circ}$ \\
\hline Mars & $0 ; 31,26,39,18,3,12^{\circ}$ & $0 ; 31,26,40,31,59,30^{\circ}$ & $0 ; 31,26,38,46,4,40^{\circ}$ \\
\hline Venus (arg.) & $0 ; 36,59,30,28,43,22^{\circ}$ & $0 ; 36,59,29,32,28,56^{\circ}$ & $0 ; 36,59,29,35,36,20^{\circ}$ \\
\hline Mercury & $3 ; 6,24,6,59,35,51^{\circ}$ & $3 ; 6,24,6,59,35,51^{\circ}$ & $3 ; 6,24,8,17,44,28^{\circ}$ \\
\hline (arg.) & & & \\
\hline
\end{tabular}

Table 3: Tabulated mean motions for 20 years and implicit daily mean motions according to the Tables of Mechelen (Versions A and B) and the Tables of Pisa. 


\begin{tabular}{|l|l|l|l|}
\hline & Saturn & Jupiter & Mars \\
\hline Ptolemy & $0 ; 57,7,43,41,43,40^{\circ} / \mathrm{d}$ & $0 ; 54,9,2,46,26,0^{\circ} / \mathrm{d}$ & $0 ; 27,41,40,19,20,58^{\circ} / \mathrm{d}$ \\
\hline Tables of Pisa & $0 ; 57,7,45,11,57,3^{\circ} / \mathrm{d}$ & $0 ; 54,9,3,22,3,12^{\circ} / \mathrm{d}$ & $0 ; 27,41,40,56,40,25^{\circ} / \mathrm{d}$ \\
\hline al-Battān̄ & $0 ; 57,7,44,55,8,11^{\circ} / \mathrm{d}$ & $0 ; 54,9,3,51,1,17^{\circ} / \mathrm{d}$ & $0 ; 27,41,40,31,45,1^{\circ} / \mathrm{d}$ \\
\hline Toledan Tables & $0 ; 57,7,44,53,10^{\circ} / \mathrm{d}$ & $0 ; 54,9,3,51,8^{\circ} / \mathrm{d}$ & $0 ; 27,41,39,13,10^{\circ} / \mathrm{d}$ \\
\hline Mechelen A & $0 ; 57,7,43,58,38,41^{\circ} / \mathrm{d}$ & $0 ; 54,9,3,45,13,26^{\circ} / \mathrm{d}$ & $0 ; 27,41,41,10,41,10^{\circ} / \mathrm{d}$ \\
\hline Mechelen B & $0 ; 57,7,43,17,0,25^{\circ} / \mathrm{d}$ & $0 ; 54,9,3,53,7,31^{\circ} / \mathrm{d}$ & $0 ; 27,41,39,56,44,51^{\circ} /$ \\
\hline
\end{tabular}

Table 4: The mean motions in anomaly of the superior planets according to Ptolemy, alBattānī, the Tables of Pisa, the Toledan Tables, and the Tables of Mechelen (Versions A and B). 